NBER WORKING PAPER SERIES

ORIGINAL SIN AND THE GREAT DEPRESSION

Michael D. Bordo

Christopher M. Meissner

Working Paper 27067

http://www.nber.org/papers/w27067

\author{
NATIONAL BUREAU OF ECONOMIC RESEARCH \\ 1050 Massachusetts Avenue \\ Cambridge, MA 02138 \\ April 2020
}

Helpful comments from seminar and conference participants at the Monetary and Financial History Conference Federal Reserve Bank of Atlanta, the 2015 World Economic History Conference (Kyoto), UC Davis, UC Berkeley, and the Hong Kong Institute for Monetary Research are acknowledged. Alain Naef provided significant feedback. We thank Barry Eichengreen and Wilfried Kisling for generous help with data and sources and Sara Cochrane and Humberto Martinez Beltran for research assistance. Corresponding author: Christopher M. Meissner, University of California, Davis One Shields Avenue Davis, CA 95616 email: cmm@ucdavis.edu. Neither author has any financial conflicts of interest. The views expressed herein are those of the authors and do not necessarily reflect the views of the National Bureau of Economic Research.

NBER working papers are circulated for discussion and comment purposes. They have not been peer-reviewed or been subject to the review by the NBER Board of Directors that accompanies official NBER publications.

(C) 2020 by Michael D. Bordo and Christopher M. Meissner. All rights reserved. Short sections of text, not to exceed two paragraphs, may be quoted without explicit permission provided that full credit, including $\odot$ notice, is given to the source. 
Original Sin and the Great Depression

Michael D. Bordo and Christopher M. Meissner

NBER Working Paper No. 27067

April 2020

JEL No. F31,F34,N10,N2

\begin{abstract}
$\underline{\text { ABSTRACT }}$
Was foreign currency denominated debt a determinant of exchange rate and monetary policy during the Great Depression? Policy makers of the day thought so. High-frequency bond price data show depreciation was associated with elevated risk premia on public debt. We also show that foreign currency debt was a determinant of exchange rate policy during the Great Depression. The gold standard heightened exposure to global shocks and prolonged the Great Depression. Why then did countries hesitate to jettison the monetary technology? Multiple factors have been identified in the literature ranging from economic and political considerations to social preferences for monetary stability. We find that foreign currency debt and trade patterns, both shaped by history and geography, had a significant impact on these choices and hence on economic stability. The effect is likely to be about half as large as the output gap in determining exchange rate policy.
\end{abstract}

Michael D. Bordo

Department of Economics

Rutgers University

New Jersey Hall

75 Hamilton Street

New Brunswick, NJ 08901

and NBER

bordo@econ.rutgers.edu

Christopher M. Meissner

Department of Economics

University of California, Davis

One Shields Avenue

Davis, CA 95616

and NBER

cmmeissner@ucdavis.edu 


\title{
Original Sin and the Great Depression*
}

\author{
Michael D. Bordo \\ Rutgers University \& NBER \\ Christopher M. Meissner \\ University of California, Davis \& NBER
}

This Draft: April 22, 2020

\begin{abstract}
Was foreign currency denominated debt a determinant of exchange rate and monetary policy during the Great Depression? Policy makers of the day thought so. High-frequency bond price data show depreciation was associated with elevated risk premia on public debt. We also show that foreign currency debt was a determinant of exchange rate policy during the Great Depression. The gold standard heightened exposure to global shocks and prolonged the Great Depression. Why then did countries hesitate to jettison the monetary technology? Multiple factors have been identified in the literature ranging from economic and political considerations to social preferences for monetary stability. We find that foreign currency debt and trade patterns, both shaped by history and geography, had a significant impact on these choices and hence on economic stability. The effect is likely to be about half as large as the output gap in determining exchange rate policy.
\end{abstract}

\section{Introduction}

A leading view of the Great Depression holds that devaluation strongly stimulated recovery (Eichengreen, 1992). Eichengreen and Sachs (1985) and Campa (1990) argued that

\footnotetext{
${ }^{*}$ Helpful comments from seminar and conference participants at the Monetary and Financial History Conference Federal Reserve Bank of Atlanta, the 2015 World Economic History Conference (Kyoto), UC Davis, UC Berkeley, and the Hong Kong Institute for Monetary Research are acknowledged. Alain Naef provided significant feedback. We thank Barry Eichengreen and Wilfried Kisling for generous help with data and sources and Sara Cochrane and Humberto Martinez Beltran for research assistance. Corresponding author: Christopher M. Meissner, University of California, Davis One Shields Avenue Davis, CA 95616 email: cmm@ucdavis.edu.
} 
economic recovery in the 1930s depended crucially upon devaluation. Countries that delayed going off gold had weaker output growth, lower exports, and lower investment rates.

The costs of the hard gold peg were seemingly higher than the benefits of exit. Nevertheless, exit from the gold standard was remarkably slow for many countries. Only a small number of financially weak commodity-exporting nations had devalued in the two and a half years between early 1929 and September 1931. Great Britain waited until September 1931 to devalue. The US did so only in 1933. France, Switzerland, Belgium and the Netherlands waited even longer. Many other countries followed either Britain or the US examples. Why did countries wait to go off the gold standard? Why did some countries follow the leaders off gold and then re-peg their currencies to these leaders if fixed exchange rates constrained monetary policy?

Was it simply that the economic orthodoxy of the time largely frowned on the instability generated by devaluation? After all, devaluation could lead to inflation, tariff retaliation, financial mayhem and default. Bordo and Redish (1990) emphasized that devaluation entailed a potential loss of credibility. Research by Simmons (1994), Wolf (2008), and Wandschneider (2008) has explored the comparative determinants of devaluation in the 1930s. The emphasis is on the balance of payments, trade relations, political economy and economic ideology. These papers mainly discussed devaluation in terms of its macroeconomic effects, while Wolf (2008) and Wandschneider (2008) considered bilateral trade relationships. Different from most of the previous research, we emphasize the currency denomination of debt as a constraint on exchange rate policy.

Indeed it appears currency denomination of debt has so far escaped a cross-country comparative quantitative analysis. While some of the country case studies have addressed the issue, the comparative quantitative literature largely has not. This is strange because historically, governments, firms, banks and households frequently contracted repayment of debt in gold or in a fixed amount of foreign currency, much as is the case today. The implications of these types of debt contracts for exchange rate policy and the balance of payments have yet to be thoroughly examined in the context of the comparative outcomes during the Great Depression. Most work to date considers the balance of payments to be a function of the general stance of monetary policy.

Currency denomination of debt was in fact paramount based on our reading of a range of secondary sources and contemporary sources. We illustrate this by showing that 
financial markets in London and New York recognized depreciation as problematic for repayment of foreign currency debt.

To show this, we use the sudden devaluation of sterling in mid-September 1931 as a natural experiment to gauge the impact of nominal exchange rate changes on sovereign borrowing costs. Using weekly and daily data on bond yields, currency denomination of debt, and exchange rates, we find that markets penalized devaluation for debtors obliged to re-pay in strong currencies. Higher bond yields compensated investors for the heightened risk of default. In sum, currency risk was transformed into default risk.

In light of this, we also analyze exchange rate policy through the lens of a simple static theoretical model developed by Bénassy-Quéré (1996). The model shows how foreign currency debt and trade linkages affect desired exchange rate fluctuations. We estimate the structural equilibrium relationship from this model which relates exchange rate movements and the main components of the balance of payments.

We find that governments tended to limit exchange rate movement between 1925 and 1938 against those currencies in which their debt was denominated. Trade also plays a role. This observation partially rationalizes why some countries opted to devalue but to continue pegging to sterling after 1931 whilst others, those carrying greater US dollar debt, were more inclined to follow the dollar and US monetary policy. The marginal impact of higher foreign currency debt is comparable to the effect of the output gap after 1928. The implication then is that the timing of the recovery from the Great Depression depended in a significant way on exposure to foreign currency debt as well as the severity of the downturn.

The negative effects of depreciation in the face of foreign currency debt were emphasized heavily in the East Asian financial crisis. Recent events in Europe in the Global Financial Crisis have also paid some attention to this issue. Hard currency debt and financial instability were also a feature of the Great Depression. Despite the ubiquitous and recurrent nature of the problem, external debt issued and payable in foreign currency is not traditionally emphasized as a significant constraint or problem in the 1930s.

This is odd considering that League of Nations and United Nations data, which we rely on in this study, reports that the average ratio of foreign public debt to total public debt for a large set of countries was close to $60 \%$ in 1930. Eichengreen and Hausmann (2005) argue that foreign currency debt is usually imposed on countries regardless of their credibility or fiscal reputation. They call this original sin. As we discuss below, the record 
is slightly more nuanced, yet these debt contracts do not seem to correlate with many macroeconomic observables and are mainly a feature imposed by international capital markets on nearly all borrowers. For our purposes, this helps us credibly identify the impact of foreign currency debt on exchange rate policy. Moreover, the particular currency of denomination seems to be strongly related to historical political and economic connection and to geography.

Theoretical work by Céspedes, Chang, and Velasco (2003) suggests that devaluation can have negative output effects when foreign currency debt makes up a significant fraction of the total, when leverage is high, and when the responsiveness of exports to depreciation is low. Consistent with this, our preliminary examination of data from the 1930s suggests that the higher the share of foreign currency debt to total debt, the longer nations waited to devalue. In some sense this rationalizes how, even if the gold standard was ultimately a detriment to recovery, why policy makers were hesitant to devalue. It also sheds light on the path countries followed subsequent to devaluation. Why did countries choose to continue pegging to one currency or another if they had already abandoned the idea of the gold standard and its constraints on monetary policy?

Our conclusion is that foreign currency debt was an important constraint on exchange rate policy throughout the 1930s. Once major nations, which themselves did not suffer from original sin devalued, or debt had been eliminated via repayment or even default, emerging markets were somewhat more liberated from the constraints of the gold exchange standard. In the meantime, nations maintained exchange rate stability against the currencies in which their debt was denominated exacerbating the downturn. The "public good" or externality associated with devaluation and monetary policy by leading nations is a key to understanding global economic downturns like the Great Depression.

\section{Currency Mismatch in the Global Economy}

Countries, banks, firms, and households frequently borrow in foreign currency rather than in domestically issued currency. This is not always their choice. Eichengreen and Hausmann (2005) dubbed this phenomenon original sin. Advanced and low income countries alike borrow in foreign currency. Historically, and even at present, only a handful of leading and large countries are able to issue debt on international markets payable in their own currency. Although many countries issue debt domestically payable in local currency, foreign debt is still most often denominated in foreign currency. Even today, although the 
issue has abated somewhat, it has not completely disappeared (McCauley, McGuire and Sushko, 2015 and Alfaro, Asis, Chari and Panizza, 2019).

What drives this feature of the data? Flandreau and Sussman (2005) suggest size and liquidity are sufficient to escape original $\sin$. In the late $19^{\text {th }}$ century, Russia, a financial basket case, and Austria-Hungry with a highly volatile exchange rate, were able to issue in domestic currency. France and Great Britain were the only other countries able to do so.

Oppositely, many countries with sound fiscal and monetary policy reputations are prone to original sin (Eichengreen and Hausmann, 2005). Australia, Canada, and the United States all suffered from original sin (Bordo, Meissner and Redish, 2005). Apparently financial development and sound public finance are not sufficient to eliminate gold clause debt or foreign currency borrowing.

We are mainly concerned in this paper with government bond issues on the leading capital markets of London and New York. Government bonds listed on the New York stock exchange were universally payable in US dollars at the legal parity at time of issue. If the local currency depreciated against gold, and even if the dollar were to be devalued, investors expected to be repaid in a fixed amount of gold - namely 1 ounce of gold for every $\$ 20.67$ of principal or interest payable.

In London, matters were slightly more complicated. We rely on detailed information about individual bond issues provided by The Stock Exchange Official Intelligence. This source reveals that nearly all bonds issued in London were payable in sterling when payable in London. The Economist (26 September, 1931 p. 571) noted that Germany's Dawes loans and the Young Plan debt as well were "issued in this country on a sterling basis". For the British colonies and the greater Commonwealth, all issues in London were payable in sterling. After sterling's devaluation in September 1931, it was a matter of debate whether Australian and New Zealand debt was meant to be paid in British sterling or local pounds. ${ }^{1}$ Ultimately it is was determined that London-issued debt was payable in British sterling.

For several leading countries, public debt was made payable in British sterling when issued in London. The Economist (26 September, 1931, p. 571) noted that, "...A number of sterling overseas loans have been made on a gold basis, the principal and interest being

\footnotetext{
${ }^{1}$ Drummond (p. 103 1981) notes: "In all three countries (Australia, New Zealand and South Africa) ordinary people and even financiers were inclined to believe that a pound is a pound regardless of provenance." The surrounding discussion relates to the actual price of British sterling in terms of local sterling which diverged from parity. We discuss this further below.
} 
payable in other currencies at a fixed rate of exchange, based on the gold parity of sterling." But more often than not, the Stock Exchange Official Intelligence reveals that bonds carried a clause that allowed coupons and principal to be paid at "sight" exchange rates (against London) in various continental markets (e.g., Paris, Berlin, Amsterdam, Hamburg, Geneva) or the home market. Danish and Swedish bonds were often issued in multiple currencies including sterling. Investors or debtors had a choice of currency in which to be paid or in which to pay. The impact on the burden of debt would then depend on whether investors required repayment at the "highest" exchange rate possible (very likely) and exchange rates on the markets listed on the bonds. Another type of bond includes those cross-listed in New York and London. Any such bond had the option to be paid in New York in US gold dollars (\$20.67/oz.) at the choice of the bond-holder.

Foreign currency public debt data for the interwar period was compiled by the United Nations (1948). ${ }^{2}$ These data list the outstanding principal of public debt payable or denominated in various currencies (largely sterling and dollars). ${ }^{3}$ Figure 1 shows the foreign currency debt-to-exports ratio in 1928 for a sample of the countries with usable data in United Nations (1948). Most foreign currency debt in 1928 was payable in US dollars or British sterling. The range of foreign debt to export ratios was 0 (USA and Turkey) to above 3.3 for Portugal and Panama. The median was 0.91, and the mean was 1.16. The interquartile range was 1.07 with a $25^{\text {th }}$ percentile of 0.45 and a $75^{\text {th }}$ percentile of 1.52 .

Effective exchange rate volatility was limited for most countries between 1926 and 1929. Between 1929 and 1935 exchange rate movements were often extreme. These fluctuations had a significant impact on the value of foreign debt expressed in the local currency. In 1929 our dataset shows that Denmark had 43 percent of its foreign debt denominated in USD, 10 percent in GBP and the remainder mostly in Swedish kronor. Figure 2 for Denmark between 1928 and 1934 shows the rise in foreign and total debt expressed at current exchange rates relative to debt values at official exchange rate parities in percentage terms. We also plot the percentage deviation of the kronor price of one US dollar relative to its initial parity of 1928. Exchange rate depreciation of over $70 \%$ by $1932 / 33$ was associated with a 55\% increase in the kronor value of foreign debt and a $30 \%$ rise in the value of total debt. Figure 3 and Figure 4 show similar results for Norway and Chile. For Chile, which experienced massive depreciation, foreign debt measured in local

\footnotetext{
${ }^{2}$ We thank Barry Eichengreen and his co-authors Livia Chiţu and Arnaud Mehl for making the digitized version of these data available to us. We say more about these data below.

${ }^{3}$ This particular source is not specific about whether debt was payable at a fixed exchange rate or not.
} 
currency was 3 times higher by 1935 than it had been in 1930. Clearly, exchange rate fluctuations, even for relatively advanced countries like Denmark and Norway, had the capacity to complicate public finances.

In the British Empire, exchange rate movements were monitored and frequently discussed. Australia, a commodity exporter, had already devalued relative to gold parity (and sterling) from October 1930 by 8.5\%. In January, 1931, the Australian pound had depreciated by $30 \%$ against sterling relative to 1928 and to its historical one-to-one parity. Australia's balance sheet in 1928 was composed of sterling liabilities to the tune of $£ 5$ per person and exports totaling $£ 25$ per person (Commonwealth Bureau of Census and Statistics, 1934 p. 885). Imperial banks held a quantity of sterling reserves to manage their currency markets. Policy makers noted that "export prices...had declined by the end of 1931 to about 32 percent of the 1927-28 level...while at the same time remained fixed in sterling...import prices fell very much less than export prices....(and) total cessation of oversea long-term loans" (Commonwealth Bureau of Census and Statistics, 1932 p. 885). It was noted that sterling's depreciation in September 1931 led to a "corresponding reduction in the real burden of interest payments by Australian governments." (Ibid. p. 887). However Australia reacted almost immediately by devaluing relative to gold by the same amount as Britain so as to keep the Australian pound pegged to sterling but with a roughly $30 \%$ premium relative to the old gold parity. Intense austerity and a default on domestic bondholders featured in Australia's policy response. There was ultimately no default on foreign debt. The Premier of New South Wales' motion in early 1931 to suspend overseas interest payments until such time that interest on debt could be re-negotiated down was rejected by the Premiers' conference.

In New Zealand, matters were much the same, although policy was slightly more cautious than in Australia in terms of devaluation. From January 1931 the New Zealand pound had been devalued by about $10 \%$ against sterling. This was the premium maintained until 1934. Like in Australia, it was noted that the fall in export prices (expressed in home currency) after $1927 / 28$ led to a rise in the burden of payment of interest of $60 \%$ as of 1931/32. (New Zealand, 1932). New Zealand mulled over a number of policy responses including exchange control and further devaluation but little action was taken prior to January 1933 when the country opted for a 25\% devaluation against sterling (Drummond, 1981).

In a response to a contemporary government-sponsored report on public finances, A.D. Park replied that "New Zealand is linked with Great Britain by strong ties of 
sentiment, trade and debt, and it would be inadvisable to make any permanent change in the basis of New Zealand currency without full discussion of the matter with the British authorities." He also suggested that "...intentional depreciation of the currency would undoubtedly have a much greater (negative) effect on our credit." (New Zealand, 1932 p. $39)$.

Drummond (1981) also highlights the implications of sterling debt for currency policy in other major economies of the British Empire such as Canada, India, and South Africa. In Canada, following sterling's devaluation, the question, again, was whether to un-tether the Canadian dollar from the gold parity. T.B. Macaulay, a business leader recommended an immediate depreciation of 20-25\% against gold (and the US dollar). However, Prime Minister Bennett, was intensely worried about the cost of repaying foreign debt in terms of local currency Drummond (1981). In September 1931 the Prime Minister wrote, "I feel sure that those who recommend this country to go off [the] gold standard do so without recognition of the obligations payable by this country in New York, to say nothing of the obligations of private industries and corporations." (Drummond, 1981 pp. 60-61). Bordo and Redish (1990) analyzed the Canadian debt position in the early 1930s finding small "flow" losses from valuation effects and depreciation. Their paper concluded that Canada maintained exchange rate stability due to concerns about credibility. Bordo and Redish (1990) did not analyze the importance of trade flows and stability in the balance of payments which is an alternative hypothesis.

In India, beset by falling export revenue, major political uncertainty and the everpresent "home charges" (i.e., payments to the UK denominated in sterling such as interest on debt and civil servant pensions), exchange rate policy was paramount. India carried a sterling debt of roughly $£ 350$ million (roughly $£ 1.66$ per person), had sterling outlays of $£ 30$ million per year and possessed roughly $£ 42$ million of reserves. Markets feared a depreciation and default "...but the India Office would not hear of a fall in the rupee". (Drummond, 1981, p. 34) As melodramatic as that might sound, India ultimately held the line by pegging to sterling at the pre-September 1931 rate of 1 pound 6 shillings. Exchange controls helped prevent a disastrous outflow of speculative capital and loss of reserves.

In other countries, similar dynamics applied. With the onset of the Great Depression, the burden of public debt increased for many reasons: exchange rate movements, falling incomes and price levels, lower exports and plummeting commodity prices. Debt default was not un-common in the period amongst many South American nations. In addition, Germany and others suspended, and then postponed, reparations payments after the Hoover 
Moratorium of 1931 and the Lausanne Conference later in 1932. Allies also suspended repayments of official wartime obligations. While the economic crisis in general took a toll on capacity to re-pay, exchange rate movements were always a key concern for those countries trying to manage their debt and capital markets priced debt accordingly. Appendix B shows the year in which countries defaulted on sovereign repayments, if any, and the year they exited the gold standard. Countries that defaulted before they left the gold standard waited an average of 2.6 years before going off the gold standard. Countries that went off gold first waited an extra 1.5 years to default. Other countries defaulted and de-pegged at the same time. A majority (32 of the 60 countries listed here) never defaulted in this period.

\section{Capital Markets, Bond Yields and the Exchange Rate}

In this section we explore exchange rate movement as a determinant of sovereign default risk. It is clear that policy makers and markets were aware of the de-stabilizing impact on public finances of a weakened exchange rate. Gauging the market's reaction to exchange rate changes is naturally complicated. One simple approach would be to correlate the yield spread of a benchmark long-term, internationally issued bond with domestic exchange rate movements. Such a naïve regression of the bond spread on the exchange rate could be problematic. Other economic forces and shocks driving both the exchange rate and default risk could bias an estimate of the elasticity of the bond yield to the exchange rate.

To deal with these endogeneity issues, we use the British devaluation of sterling which was publicly announced on Monday September 21 $1^{\text {st }}, 1931$ as an exogenous driver of exchange rates. The exact timing and magnitude of the overnight devaluation against gold was largely unanticipated by markets despite the fact that the British economy and financial system had been under strain throughout 1931. Accominotti (2009) notes that even as early as October 1929 there was "world-wide concern". The Macmillan report, published in 1930, also featured opinions from several influential economists that devaluation of sterling would eventually be required. Keynes was not amongst them, proposing instead tariffs, export bounties and other policies to increase domestic demand. Many, including Montagu Norman, believed that sterling's international position would be damaged due to a devaluation. Experts recognized that external liabilities like allied war debts, payable in US gold dollars, would increase in value with devaluation (Cairncross and Eichengreen, 1983) 
Nevertheless the decision to devalue was taken on Friday September 19 by the Bank of England's deputy governor in response to an acceleration of gold reserve losses during the week and a failure to secure more international credit (Einzig, 1932). Formal approval was given by parliament on 21 September. Bank of England governor Montagu Norman, en route to England from Canada on a steamship, was sent the coded radio message over the weekend "Old Lady Goes off on Monday". He allegedly mis-understood this message to be in reference to his mother's vacation and upon arrival in the UK on 23 September was in shock to hear the news (Boyle, 1967).

In the days and weeks immediately following the devaluation, many countries' exchange rates were determined largely by this British policy choice and pre-determined factors. Consequently, a near ideal data set for cleanly estimating the elasticity of bond yields with respect to a surprise depreciation is an event study of bond yields around the time of the British devaluation. ${ }^{4}$

The bond market's reaction to the exchange rate is a function of at least three factors. The first is a currency risk/default risk channel. For debt issued and payable in a particular international currency such as sterling, an appreciation against sterling would tend to lower default risk compared to a currency that depreciated. The second is a macroeconomic channel, one which contemporary observers were well aware of in 1931. Appreciation leads to lower exports, deflation, a rise in the burden of internal debt, the erosion of export profitability etc. These issues were highlighted in discussions of the impact of the new British exchange rate policy in The Economist (September 26, 1931 p. 571). Appreciation might be expected to raise bond yields in this case. Finally, a "market effect" or demand effect is in play. Bondholders of sterling debt, upon announcement, might be inclined to sell these assets in favor of bonds payable in gold or in currencies that were expected to stay high relative to sterling whether listed in New York, London or the continent. ${ }^{5}$ Of course, expectations about exchange rates due to local changes in policy come into play as we move away from 21 September, 1931.

We summarize these three factors and their likely impact on bond prices in a $2 \times 2$ matrix in Table 1. Columns in the matrix relate to exchange rate policy: peg to sterling or

\footnotetext{
${ }^{4}$ Bordo, Meissner and Weidenmier (2009) followed a similar approach in the 1870s when France demonetized silver. They found that countries that stayed on a silver standard had higher bond yields on gold clause debt relative to gold standard countries.

5 "The prices of the gold loans were, of course, marked up this week in terms of sterling, except in those cases where default had already been committed or was expected." The Economist (e.g., September 26, 1931 p. 571)
} 
continue pegging to gold (i.e. appreciate against sterling). Other courses of action existed such as depreciation against the pound or managed floating with a devaluation (against gold) somewhere between gold parity and a full peg to sterling. Countries and dependencies in the British Empire generally pegged to sterling. South Africa however engineered a 10\% and then a $17 \%$ appreciation against its par values with sterling while Canada appreciated by $10 \%$ against sterling in 1931/32. France, the US and Belgium amongst others continued pegging to gold in the weeks after 21 September, 1931. The rows in the matrix correspond to the currency denomination of debt: payable in sterling vs. payable in currency (e.g., US dollars) at the historical gold parity. This two-way division is much closer to capturing the realm of possibilities. Default for liquidity or solvency reasons is a missing feature of this simple model.

Based on the possibilities from Table 1 we run event-study regressions of the following form on weekly bond yield data

$$
\begin{gathered}
\ln \left(\text { Yield }_{\text {bit }}\right)=\kappa+\beta_{1}\left(\text { gold clause }_{b} \times \text { gold standard }_{i t} \times \text { post }_{t}\right)+ \\
\beta_{2}\left(\text { gold clause }_{b} \times \text { sterling peg }_{i t} \times \text { post }_{t}\right)+ \\
\beta_{3}\left(\text { gold standard }_{i t} \times \text { post }_{t}\right)+\beta_{4}\left(\text { sterling peg }_{i t} \times \text { post }_{t}\right)+\beta_{5}\left(\text { gold clause }_{i t} \times \text { post }_{t}\right)+\mu_{b}+\delta_{t}+\varepsilon_{b t}
\end{gathered}
$$

where $b$ denotes a bond, $i$ indexes a country, $t$ indexes a week, gold clause is an indicator equal to one if a bond is payable in a currency still maintaining a gold peg, gold standard is an indicator equal to one if a country has not devalued the exchange rate from the gold parity, sterling peg is an indicator equal to one if a country maintains a peg to sterling, post $_{t}$ is an indicator equal to one in the weeks following the British devaluation of sterling which occurred on 21 September, 1931, $\mu_{b}$ is a set of bond fixed effects, $\delta_{t}$ is a set of week fixed effects and $\varepsilon_{b t}$ is a possibly heteroscedastic, mean zero, finite variance error term.

We interpret $\beta_{1}$ as the relative impact on bond yields for gold standard countries with gold clause debt in the wake of the British devaluation. This is an effect measured relative to countries that either devalued against sterling or which did not devalue against gold as much as sterling (i.e., the managed floaters). We expect this coefficient to be negative if the foreign exchange effect is strong enough. In other words, this is consistent with a view that markets priced debt higher when the exchange rate held steady against gold. 
Similarly, $\beta_{2}$ measures the impact on bond yields of gold clause debt when a country chose to peg to sterling after 21 September, 1931 relative to other floating countries. A positive coefficient is consistent with the idea that markets predicted a higher chance of default due to the increased burden of debt repayment due to a depreciation of roughly $20 \%$ against gold. In addition, the interactions between gold adherence and the post-9/21 period and the sterling bloc-post indicator control for the macroeconomic channel. If $\beta_{4}$ is negative this implies that strong devaluation against gold would lower default risk, separate from the FX channel.

The interaction between the gold clause indicator and the post-event dummy controls for the market effect that might have favored gold debt over sterling debt, even for floating countries, in a context of the British devaluation. Time dummies control for market wide portfolio re-allocations and the bond fixed effects allow for country and currency repayment differences in yield levels across bond types throughout.

\subsection{Weekly Data}

We compile weekly data on bond prices from the set of colonial and sovereign bond issues listed in every Saturday issue of The Economist between 1 August, 1931 and October 17, 1931. Bond prices refer to closing prices on the Wednesday before publication (i.e., Wednesday 29 July for the August 1 issue). The London sample comprises 46 long-term bonds for 26 countries and 9 British dependencies. We also add a small sample of 15 more bonds for 7 countries from the New York market available from the New York Times. We used the highest closing price in the New York Times for each bond and the listed coupon rate.

The Economist also lists exchange rates and coupon interest rates. We calculate current yields (coupon yield divided by bond price) for each bond listed. In addition we compile the foreign currency clauses for each London bond from the Stock Exchange Official Intelligence. These are coded following the discussion above on currency denomination of debt. All New York debt was payable in gold dollars at the official parity of $\$ 20.67 /$ oz of gold.

The pre-event window in the bond market is the eight weeks prior to the sterling devaluation of 21 September, 1931. The post-event window is the six weeks after this devaluation. 
We use countries that did not peg to gold or sterling as a comparison group. As mentioned above, there were four categories of countries: those which pegged to sterling, those which pegged to gold, those which devalued relative to gold but not by as much as sterling and those which underwent further devaluation and depreciation or appreciation beyond Sterling's decline in value. The latter category comprises few countries in our sample (Brazil, Mexico, and Argentina). A peg to sterling requires the nominal exchange rate with the pound not to have appreciated against sterling more than $3.5 \%$ and not to have depreciated by more than $1 \%$. A gold peg requires that the nominal exchange rate against sterling to have appreciated by between $17 \%$ and $26 \%$ in each of the post period weeks. Floaters and falling regimes are those falling outside of these ranges $(3.5 \%$ to $17 \%$ appreciation or a depreciation beyond $1 \%$ ).

One key issue is whether exchange rate movements are uncorrelated with the ongoing economic shock. Empire countries, and eventually several Scandinavian countries, followed Britain and maintained long-standing pegs with the notable exception of South Africa. Many of these countries devalued against gold and then re-pegged to sterling at slightly depreciated nominal exchange rates.

Other countries, some of which imposed exchange controls, largely stuck to gold or limited the amount of the depreciation. Exchange control countries could and did ration exchange so as to maintain an over-valued exchange rate, at least in the short-run. Given that countries mostly fell in line along colonial obligations, we assume that the exchange rate movements in the short-run were largely unaffected by other economic shocks affecting market perceptions of public finances. Still, longer-run expectations about the economy and exchange rate policy may be at play.

\subsection{Event Study Results: Weekly Data}

Table 2 shows results for regressions based on our event study regression equation. We explore results for two samples: London bonds only and New York and London bonds. In all specifications, gold country yields dropped by an average of 11 log points relative to the comparison group of floating countries that also had gold debt. Maintaining a strong exchange rate against sterling gave the market reassurance that debt was more likely to be repaid on time and in full.

On the other hand, countries following Great Britain off gold and depreciating their exchange rates by about $20 \%$ (relative to gold parity) paid a penalty of 15 log points in New York relative to floating countries. In London, these bonds were apparently treated 
differently than in New York. A smaller premium, or rise, in yields is apparent, of about 5 log points when focusing only on the London market. This coefficient is not significant when we include the Gold Clause-post indicator likely because there are very few gold bonds in London for non-gold countries in our sample.

The bottom line from Table 2 is that policy makers were right to be worried about exchange rate movements against gold when debt was payable in gold currency. ${ }^{6}$ Depreciation and valuation effects could increase the net outflow of capital weakening the balance of payments. Such pressure would undoubtedly be met with expectations of greater difficulty in maintaining either debt repayment or exchange rate commitments. We now turn to an exploration of how policy makers re-acted in the face of these markets.

\subsubsection{Event Study Results: Daily Data}

We also explore an event study design using daily data. Data cover 28 days and include each day for which the Financial Times reported data between September 7, 1931 and October 8, 1931. The pre-event window includes the 12 days of data up to Saturday 9/19/1931. The post-event window encompasses 15 days beginning with Tuesday 9/22/1931. We omit Monday 9/21/1931. The sample encompasses 45 countries and 160 bonds from the New York and London markets. We omit bonds that are in default according to the Stock Exchange Official Intelligence.

Our specification remains largely the same as that for the results in Table 2. There are no countries that devalue against gold more than sterling did in this sample. The baseline comparison group includes countries that devalued against gold by less than sterling but depreciated against gold by more than 2 percent. We classify sterling peggers as those that devalued after $9 / 21$ and were within $+/-4 \log$ points of the pre-event $\log$ sterling exchange rate in the post-event window. The sample includes very few sterling pegs with gold debt (3 Australian bonds and 2 British bonds all listed in New York).

Table 3 shows results for our daily regressions. Countries that stayed on the gold standard and with gold-debt, experienced an extra 13 log point decline in bond yields (column 3) relative to the comparison group. The market channel is visible in column 3 too

\footnotetext{
${ }^{6}$ We used the log of the bond price, the percentage spread with the British consol as a reference yield, and the level of the spread as alternative dependent variables. All results are qualitatively consistent with those reported here.
} 
and suggests gold debt, even when payable by a country with a floating currency was less risky or in higher demand relative to sterling-denominated debt. Finally, a macro effect is visible. Countries devaluing and pegging to sterling witnessed an extra reduction in yields of about $8 \log$ points.

We also estimate a fully flexible model for the event study allowing for separate coefficients on the gold clause debt-gold standard interaction term for each period. The treatment group in this model is the group of countries which were always on gold after sterling's devaluation in the post-event window. The comparison group in this sample is strictly the group of countries that maintained a sterling peg throughout the post-event window and had debt payable in gold. We eliminate 9/21/1931 from the sample and use 9/19/1931, the first lagged date from the event as the reference point. ${ }^{7}$

After sterling's devaluation, gold countries see an immediate drop in their bond yields by about $10 \mathrm{log}$ points. Over the following two weeks, yields declined by another $10 \log$ points relative to sterling countries. Figure 5 shows coefficients and $95 \%$ confidence intervals for each period. The results are similar to those in Table 2 and 3 . In addition, there is no evidence of a pre-trend for countries that would eventually maintain the gold standard during the event window. Our bottom line is that markets perceived gold-denominated debt to be a larger burden for countries that devalued against gold.

\section{Exchange Rate Policy and Foreign Currency Debt}

According to recent quantitative assessments of exchange rate policy in the 1930s, a large number of factors influenced policy makers' decisions. Pioneering research by Simmons (1994) highlighted political economy and balance of payments issues. In a nearly exhaustive analysis, Nikolaus Wolf (2008) studied the hazard rate of quitting the gold standard. He considered the net international investment position, monetary policy credibility, trade network and alliance effects, and the political constraints that affected how balance of payments adjustment might be effected. In addition, the severity of the depression measured by the extent of deflation and presence of financial crises also were considered. Eichengreen and Irwin (2010) also showed that trade policy and exchange rate policy acted as substitutes, so that tariffs acted to insulate a gold standard country from global shocks. While previous studies like Wandschneider (2008), Wolf and Yousef (2007), and Wolf (2008)

\footnotetext{
${ }^{7}$ Results for Figure 5 and in Table 3 cluster standard errors at the country level. Results are robust to two way clustering on the country and bond level.
} 
have emphasized a multitude of factors, one issue that has not been examined in depth is the currency denomination of debt.

We follow an in depth exploration of what happens when the current account balance is the main focus of policy makers. The simple economics of the current account shows that exchange rate policy is paramount. Although net exports increase with (real) depreciation to the degree the Marshall-Lerner condition is satisfied, net interest payments abroad are increasing one-for one with the percentage depreciation in the exchange rate in the presence of foreign currency debt. The trade-off for achieving a target for the balance of payments depends on trade networks as well as the denomination of foreign currency debt.

\subsection{The Balance of Payments and Exchange Rates: Theoretical Model}

Bénassy-Quéré (1996) presents a simple and intuitive model of the optimal exchange rate peg with the tradeoffs highlighted above. We follow her approach and interpret it in the context of the Great Depression. The model asks: what should a small-open economy do with its exchange rate when both the trade balance and debt service are important? We consider the three country version of the model. There are two large countries as potential anchors (e.g., the US and Great Britain). A small-open economy makes a choice about its exchange rate. Debt can be denominated in either US dollars/gold or in sterling. Trade with the two large countries (or these currency blocs) accounts for all trade flows. For our purposes, we will consider a short-run where the real and nominal exchange rate coincide. We also assume away strategic responses by studying the policy of a small-open economy. The model is static.

First assume that the small country aims to stabilize the current account, $b$, around an objective, $b^{*}$ by choosing the appropriate exchange rates against the US and Great Britain. The current account equals the sum of net exports and debt service. The objective function is then

$$
\min _{e} \Omega=\left[b(e)-b^{*}\right]^{2}
$$

The current account is simplified to the following expression which is the sum of the trade balance and debt service payments:

$$
b(e)=\alpha \gamma e-\beta f+b_{0}
$$


Where $e$ is the logarithm of the real effective exchange for trade flows, $f$ is the logarithm of the real effective exchange rate for foreign debt payments, $\alpha$ is the ratio of exports to GDP, $\gamma$ is the sum of the (absolute values) of the export and import elasticities minus 1, and $\beta$ is the ratio of foreign debt service to GDP.

Define the real effective exchange rates for trade flows $(e)$ and debt $(f)$ as

$$
\begin{aligned}
& e=\alpha_{\$} e_{\$}+\alpha_{£} e_{£} \\
& f=\beta_{\$} e_{\$}+\beta_{£} e_{£}
\end{aligned}
$$

Where $e_{i}(i=\$, £)$ is defined as the log of the (real) exchange rate against the dollar or pound (local currency per unit of foreign currency), $\alpha_{i}$ is the share of trade by currency/country and $\beta_{i}$ is the share of debt payments in currency $i$. Using the fact that $\alpha_{\$}+\alpha_{€}=1, \beta_{\$}+\beta_{€}=1$, and $e_{£ \$}$ (the sterling price of a US dollar) equals $e_{\$}-e_{€}$ it is easy to show that the optimal depreciation against the US dollar when the pound depreciates by $1 \%$ against the US dollar is given by:

$$
\frac{\partial e_{\$}}{\partial e_{£ \$}}=\frac{\alpha \gamma \alpha_{£}-\beta \beta_{£}}{\alpha \gamma-\beta}
$$

Expression (3) implies that when there is no foreign debt $(\beta=0)$ or when the currency share of debt is matched to the trade flows $\left(\alpha_{£}=\beta_{£}\right), \frac{\partial e_{\$}}{\partial e_{£ \$}}=\alpha_{£}$. For instance, If all trade is with Great Britain, and all debt is denominated in pounds, then the optimal response to a $1 \%$ depreciation of the pound versus the dollar is to maintain a peg with sterling. The local currency would of course then depreciate against the dollar by the same amount as sterling.

Now continue to assume all debt is denominated in pounds, but trade with Great Britain is less than $100 \%$. In this case, some appreciation against the pound is allowed in inverse relation to the share of trade with Britain. A country with a very low British trade share, (i.e., a very high US trade share), would peg closer to the dollar, appreciating significantly more against the pound.

The former cases might be empirically relevant for Empire countries like Australia and New Zealand. Roughly $42.5 \%$ of Australia's trade was with Great Britain, the rest being 
mainly with other gold standard countries. Meanwhile $90 \%$ of public foreign debt according to our data was denominated in GBP. The model predicts that countries like Australia and New Zealand would depreciate much more against the dollar than the pound. Still, for reasonable values of the economic variables of interest, the model tends to predict such countries would appreciate against sterling. This however is counterfactual to historical events. Both Australia and New Zealand pegged closely to sterling after September 1931. Clearly, as indicated in the Report of the Economic Committee in New Zealand (New Zealand, 1932) internal debt and employment mattered. Appreciation against sterling would have required further deflation. One way to combat unemployment and high debt burdens, while helping export interests would of course have been greater inflation.

The model should best be seen to provide predictions in comparative terms. Australia and New Zealand certainly pegged closer to sterling than other nations. Countries like those in Scandinavia, Canada, and Japan had trade and debt shares that were more closely matched. Canada and Japan having a significant amount of US dollar and gold clause debt (Bordo and Redish, 1990). Such countries are predicted to "split the difference" depreciating by a smaller amount against the dollar (than Australia and New Zealand) and thereby appreciating somewhat more against the pound. A country with trade flows concentrated in one country, and debt with another, trades off the exchange rate impact on trade with its impact on debt repayments. Many countries in Latin America could be seen in this light.

Generally speaking, higher shares of GBP-denominated debt or higher shares of British trade are associated with closer pegging to the pound. Figure 6 shows some examples of how the model works. In Figure 3 we assume $\alpha=0.25$, the sum of trade elasticities $\gamma=$ 1.4 , and the share of foreign debt in GDP $\beta=0.1$. We allow both the share of trade with Great Britain and debt denominated in GBP to vary between 0 and 1. Each plotted line specifies trade or debt shares with Great Britain. For instance, the top line holds the trade share with Great Britain constant at $100 \%$ and allows the debt share in GBP to vary along the $\mathrm{x}$-axis between 0 and $100 \%$. The $\mathrm{y}$-axis plots the changes against the pound for a $1 \%$ depreciation of the pound against the dollar. Negative values are appreciations and positive values are depreciations against the pound. The x-axis plots either the trade share with the UK or the share of debt denominated in GBP or both as indicated in the legend.

For example, assume a 100\% trade share with the UK, depreciation against the pound is smaller as the debt share in GBP increases. Now suppose all debt is denominated in dollars and all trade is with Great Britain as the top line in Figure 3 illustrates. Then 
the model predicts a strong depreciation against the dollar by $1.4 \%$ and a smaller depreciation against the pound of $0.4 \%$. Higher exports to Britain offset the rise in dollar debt re-payment. This stabilizes the balance of payments by stabilizing the effective exchange rate. As the share of debt denominated with Great Britain increases, the country pegs closer to sterling. Two other versions of the model vary the trade share with the UK but hold the GBP debt share at $50 \%$ or $100 \%$. Both of these show that movement against the pound declines as the trade share with Great Britain rises. In general, given a fixed level of trade with Great Britain, a higher debt share denominated in GBP implies less movement against the pound and vice versa. ${ }^{8}$

We provide three tests of this model. The first is a quasi-structural estimation of expression (3). We assume the sum of the trade elasticities minus 1 is 1.4 which is a benchmark chosen by Bénassy-Quéré (1996 p. 59). Otherwise we use observable data to construct an empirical version of expression (3). We focus only on 1932 when the pound depreciated by roughly 20-25\% following the policy action in September 1931. This allows us to have a clean, one time-depreciation of the pound versus the dollar as it comes before any policy change in terms of the gold standard in the US. The model predicts a larger movement against the dollar for a country's exchange rate as the right-hand side increases, and it also predicts a smaller change against sterling as the right hand side ratio increases.

The second and third tests are reduced form tests. First we regress the absolute change in the nominal exchange rate against the ratio of trade with Great Britain to GDP, the ratio of GBP debt outstanding to exports and the interaction of these two variables to control for the non-linearities of the model. We also include controls for the ratio of trade to GDP, foreign debt service as a share of GDP, and the change in (log of) reserves in the vector $x$. All variables are lagged by one year to avoid simultaneity bias. Since the dependent variable is bounded below by zero, we run Poisson PPML regressions in the cross section for 1932 of the following form:

$$
\mid \Delta \ln \left(e_{c, G B)} \mid=\exp \left[\gamma_{o}\left(\frac{T_{c, G B}}{Y_{c t}}\right)+\gamma_{1}\left(\frac{\operatorname{Debt}(G B)_{c t}}{\text { Exports }_{c t}}\right)+\gamma_{2}\left[\left(\frac{T_{c, G B}}{Y_{c t}}\right) \times\left(\frac{\operatorname{Debt}(G B)_{c t}}{\text { Exports }_{c t}}\right)\right]+x_{c} \theta\right]+\varepsilon_{c t}\right.
$$

\footnotetext{
${ }^{8}$ Also note that when $\alpha \gamma \approx \beta$, that is, when trade is nearly balanced against debt re-payment the optimal response is indeterminate. In this case, exchange rate variations have offsetting effects on the trade flows and debt repayments.
} 
Where $T_{c, G B}$ represents trade for country $c$ with Great Britain, $Y_{c t}$ is GDP for country $c$ in year $t$, and $\varepsilon_{c t}$ is an error term.

The third test uses a broader panel sample and studies the absolute value of the movement for a country $c$ in the (nominal) exchange rate against both the pound and the US dollar. The model is similar to the previous model, except now we are able to include in come specifications country fixed effects as well as year fixed effects which control for common shocks. Instead of only looking at GBP debt and trade with Great Britain we allow trade to be with country $j$ ( = GB, USA). This model is expressed as

$$
\mid \Delta \ln \left(e_{c j t)} \mid=\exp \left[\gamma_{o}\left(\frac{T_{c j t}}{Y_{c t}}\right)+\gamma_{1}\left(\frac{\operatorname{Debt}(j)_{c t}}{\operatorname{Exports}_{c t}}\right)+\gamma_{2}\left[\left(\frac{T_{c j t}}{Y_{c t}}\right) \times\left(\frac{\operatorname{Debt}(j)_{c t}}{\operatorname{Exports}_{c t}}\right)\right]+x_{c t} \theta+\delta_{t}+\mu_{c}\right]+\varepsilon_{c j t} .\right.
$$

We also control in $x_{c}$ for the change in the log of gold and foreign exchange reserves, the change in the log ratio of total exports to imports (i.e., the trade balance), the ratio of trade to GDP, the ratio of debt service to GDP, and the percentage deviation of GDP per capita in year $t$ from GDP per capita in 1928. Debt default was common during the Depression which would have alleviated pressure on the balance of payments. We include an interaction between the debt variable and a default indicator as well as the un-interacted default

indicator to control for this. Finally, country fixed effects are in the vector $\mu_{c}$ and $\varepsilon_{c j t}$ is an error term.

\subsection{Data}

We rely on debt data compiled by the United Nations (1948) which listed the amount of public foreign debt denominated in each currency converted to local currency at "par" exchange rates. These were converted to US dollars at constant exchange rates by Chitu, Eichengreen, and Mehl (2014). We rely on the data set assembled by Chiţu et. al. (2014) which involve some additions to the United Nations data. These data, and how they were assembled and processed, are thoroughly discussed by Chiţu et. al (2014).

A number of caveats must be issued. Cross-country comparability in data reporting and recording is always a worry. The United Nations statisticians attempted to make data as comparable as possible. Data issued in a foreign currency is allocated to the foreign debt column because it is presumably purchased by foreigners. If domestic residents purchased 
foreign currency debt, the UN or local authorities may not have recorded this debt as foreign debt. The opposite holds for domestic currency debt. The amounts involved would appear to be small. In Norway in 1940, domestic holding of foreign currency debt and foreign holding of domestic currency debt involved roughly $3 \%$ of total outstanding debt (United Nations, 1948 p. 107).

Many countries also included complicated exchange rate clauses allowing discretion in the currency of re-payment. Detailed descriptions on several bonds from the Stock Exchange Official Intelligence indicate that sometimes exchange rates were fixed at statutory rates but other times they were not. This latter issue could lead to mismeasurement of the shares of foreign currency debt. Most of these issues would have arisen after the devaluations and currency instability of 1931. In our first tests, we use data from 1931 -- before exchange rate changes complicated the recorded data and re-payment options.

United Nations (1948) collected data for up to 35 countries and colonies. The sample of countries for which we have data on both GBP and USD debt grows from 23 in 1925 to 31 in the 1930s. We dis-regard debt denominated in currencies besides the pound and dollar. The total amount of debt outstanding issued in other currencies averaged 7.9 percent of total foreign currency debt as listed in the United Nations (1948) between 1925 and 1938. The total sample of countries used in our regressions is between 11 and 15 depending on specification because of missing control variables. ${ }^{9}$

United Nations (1948) also included some information on debt service (interest and redemptions) on foreign debt for selected countries. Exchange rates are also listed in the United Nations source, although we also cross-checked these data and filled in missing values with those provided by David S. Jacks (private communication) and those used in Bordo, Eichengreen, Klingebiel and Martinez-Peria (2001). Data on bilateral trade shares come from Jacks, Novy and Meissner (2008).

Default dates are from Reinhart and Rogoff (2011). We account for default on war reparations as well as default or non-payment of inter-allied debt. Default on these debts began in 1931 with the Hoover Moratorium. Since these standstills had repercussions for the balances of payments we record them as defaults. Reserve data are from Bordo et. al. (2001) and where missing from the League of Nations (various years) as well as Bank for International Settlements (1932).

\footnotetext{
9 The countries included are: Argentina, Australia, Belgium, Brazil, Canada, Denmark, Finland, Japan, New Zealand, Norway, Portugal, Switzerland, Uruguay.
} 


\subsection{Results}

Figure 7 and Figure 8 show two tests of the structural model. Here we regress the log change of the exchange rate against the US dollar and the absolute value of the log change of the exchange rate against sterling on the ratio featured on the right hand side of (3). The sample is for 1932, the year following sterling's devaluation. Figure 7 shows the actual values and the regression line for the nominal depreciation against the US dollar in 1932 for 13 countries/colonies. The model predicts a positive relationship with a coefficient of one. The coefficient of 0.49 in this regression is lower than predicted. The heteroscedasticity robust standard error is $1.82(\mathrm{p}$-value $=0.096)$. The R-squared is 0.23. Attenuation bias is a concern given the quality of the data, especially the information on debt service. We recognize the issues of the small sample here.

Figure 8 shows the absolute value of the actual and predicted changes against sterling between 1931 and 1932. The predicted negative relationship is evident. ${ }^{10}$ The coefficient in the regression of the absolute change in sterling against the dollar is -0.38 with a heteroscedasticity robust standard error of 0.13 ( $\mathrm{p}$-value $=0.012$ ). The R-squared of the regression is a surprisingly high 0.57 .

Table 4 shows five different reduced form cross-section models for 1932 following the regression equation (4) above. The dependent variable is the absolute change in the log of the exchange rate (local currency per pound sterling) between 1931 and 1932. Control variables are lagged by one year back to 1931. The sample in columns 1-3 includes 11 countries for which all control variables, including reserves, are available. ${ }^{11}$ Columns 4 and 5 add three more countries (Japan, New Zealand, Uruguay) which had missing debt service data as a check on the robustness of the results.

The general prediction is that a country would peg closer to the pound when trade or debt linkages were higher ceteris paribus. Results in all columns are consistent with this idea. Both trade with Great Britain and more sterling debt seem to have increased the

\footnotetext{
10 Here the model predicts a negative relationship since a peg to the dollar would necessarily imply an appreciation against the pound equal in percentage points to sterling's depreciation against the dollar. This depreciation was $25 \mathrm{log}$ points in 1932. A predicted peg to sterling implies a 25 log point depreciation against the dollar.

11 The 11 countries are: Argentina, Australia, Belgium, Brazil, Canada, Denmark, Finland, France, Norway, Portugal, Switzerland.
} 
desirability of a sterling peg. While the un-interacted sterling debt variable has a positive coefficient in columns 2 and 3, the interaction term suggests that for 9 out of 11 of the countries the marginal effect is negative based on their observed ratios of trade to GDP with Great Britain. All of these results are qualitatively robust to running a linear regression instead of the Poisson model.

Results for the panel data set are presented in Table 5. ${ }^{12}$ This table uses the (absolute values of) the annual changes against both the US dollar and sterling as the dependent variable. Countries can now appear twice in the sample in a given year. Both the bilateral trade ratio and the bilateral debt-to-exports ratio are negatively associated with movements in the bilateral exchange rate. Although the interaction term is positive in this specification, the total effect is negative, as predicted by the model, for just over $70 \%$ of the sample $(70 \%$ of observations have a ratio below the threshold of 0.083 ).

Columns 4, 5, and 6 include country fixed effects. Column 4 repeats the specification of column 3 without country fixed effects. Column 5 includes a control for the percentage change in GDP per capita between the current year and 1928, the peak of the global business cycle. Column 6 drops the largest countries which also are coded as defaulting (France, UK, Germany and the US).

Trade and debt are negatively related to the absolute levels of the changes in the exchange rate. The coefficient on the interaction term between default and currency denomination of debt is positive and significant in columns 4, 5, and 6 . It is small and not significant in the first three columns. The positive coefficient implies that defaulting, or implementing a standstill, allowed for larger changes in the exchange rate relative to countries which actively re-payed their foreign currency obligations. The change in reserves is negative and statistically significant suggesting that a large loss in reserves would complicate maintaining a continued peg. The change in the trade balance is not statistically significant. In column 5 we find that the GDP gap from 1928 is negatively associated with exchange rate movement implying that a larger contraction is associated with a larger exchange rate movement. The marginal effect of the GDP gap is about twice as big as the

\footnotetext{
${ }^{12}$ These regressions include 13 countries: Argentina, Australia, Belgium, Brazil, Canada, Denmark, Finland, France, Japan, Norway, Portugal, Switzerland, and the UK.
} 
impact of foreign currency debt. ${ }^{13}$ While foreign currency debt and trade relations mattered, so did the size of the decline in aggregate demand.

Figure 9 shows the residual scatter plot of the (absolute value of the) change in the exchange rate relative to the bilateral debt ratio from a linear regression. The negative relationship between foreign currency debt and exchange rate movement is evident in this large sample.

\section{Conclusion}

With the outbreak of the Great Depression, nearly every country in the world was forced to decide whether to maintain an orthodox monetary regime or to attempt restoring domestic demand by devaluing. Markets also priced default risk into foreign currency or gold denominated debt when countries devalued. Policy makers in the 1930s were well aware of the fact that depreciation could have a very negative impact on the ability to service external debt. Officials in Australia noted the budgetary benefits of lower interest payments when sterling was devalued in September 1931 (Commonwealth Bureau of Census and Statistics, 1939). They also argued in August 1931, prior to sterling's devaluation, that a hypothetical devaluation of the Australian pound against sterling would aggravate the government deficit.

In September 1931, the UK's Treasury gifted Commonwealth nations like Australia with a devaluation of sterling. This offered the best of both worlds. Such countries could maintain their peg allowing for stability of the balance of payments. At the same time, the devaluation relative to gold worked to improve internal balance. Other countries weren’t so fortunate and stayed locked into gold much longer. Why?

Two important channels that connected nations' monetary choices were trade and debt. Historical ties shaped trade and investment connections. The choice to devalue in the 1930s also depended on monetary policy in the key creditor nation. The currency composition and amount of debt mattered for the choice to devalue, but was dependent on the actions of other nations. Leaving the gold standard was significantly more palatable after Sterling's devaluation of 1931 and even more so after the US devaluation of 1933.

\footnotetext{
13 The marginal effect is calculated after standardizing the data. A one standard deviation rise in foreign currency debt is associated with a fall in the dependent variable equal to 2.28 standard deviations at the mean of the bilateral trade variable. A one standard deviation decline in GDP per capita relative to 1928 is associated with a rise of about 5.5 standard deviations of the dependent variable.
} 
Whether a country could follow sterling off gold or had to wait for the dollar to break its gold peg was in significant part related to historical and geographic fundamentals.

Clearly the resolve to combat deflation and unemployment mattered, but these were not the only considerations for policy makers in the early 1930s. We have shown evidence consistent with the idea that the currency denomination of debt mattered for policy in the 1930s. Ceteris paribus, this factor was about half as strong on average as the output gap in the early 1930s. In explaining why the Great Depression lasted so long compared to other economic downturns, surely economic interdependence through the global economy must be considered. This does not imply, of course that a policy of autarky would have been better. Instead it signals the crucial significance of international cooperation and coordination in a globalized economy.

\section{References}

Alfaro, Laura, Asis, Gonzalo, Chari, Anusha, and Panizza, Ugo. (2019). "Corporate debt, firm size and financial fragility in emerging markets" Journal of International Economics, 118, pp. 1-19.

Bénassy-Quéré, Agnès. (1996). "Potentialities and Opportunities of the Euro as an International Currency" CEPII Working paper no. 1996-09 July.

Bank for International Settlements. (1932). "The Gold Exchange Standard" Bank for International Settlements. Monetary and Economic Department. C.B. 60.

Bordo, Michael D., Eichengreen, Barry, Klingebiel, Daniela, and Martinez-Peria, Maria Soledad. (2001). "Is the crisis problem growing more severe?" Economic policy, 16(32), pp.52-82.

Bordo, Michael D. and Redish, Angela. (1990). "Credible Commitment and Exchange Rate Stability: Canada's Interwar Experience" The Canadian Journal of Economics, 23 (2) pp. 357-380.

Bordo, Michael D., Meissner, Christopher M., and Redish, Angela. (2005). "How 'Original Sin' Was Overcome: The Evolution of External Debt Denominated in Domestic Currencies in the United States and the British Dominions 1800-2000" in Other People'S Money: Debt Denomination and Financial Instability in Emerging Market Economies. 
Barry Eichengreen and Ricardo Hausmann eds. pp. 122-153. Chicago: University of Chicago Press.

Bordo, Michael D., Meissner, Christopher M., and Weidenmier, Marc. (2009). "Identifying the Effects of an Exchange Rate Depreciation on Country Risk: Evidence from a Natural Experiment" Journal of International Money and Finance 28(6) pp. 1022-1044.

Boyle, Andrew. (1967) Montagu Norman: A Biography. London: Cassell.

Cairncross, Alec and Eichengreen, Barry (1983) "Sterling in Decline: The Devaluations of 1931, 1949, and 1967". New York: Routledge.

Céspedes, Luis F., Chang, Roberto, and Velasco, Andres. (2003). "IS-LM-BP in the pampas." IMF Staff Papers, 50(1), pp.143-156.

Chiţu, Livia., Eichengreen, Barry, and Mehl, Arnaud. (2014). "When did the dollar overtake sterling as the leading international currency? Evidence from the bond markets." Journal of Development Economics, 111, pp.225-245.

Drummond, Ian M. (1981). The floating pound and the sterling area, 1931-1939. New York: Cambridge University Press.

Commonwealth Bureau of Census and Statistics. (various years). Official Yearbook of the Commonwealth of Australia Canberra: L.F. Johnston Commonwealth Government Printer.

Eichengreen, Barry and Hausmann, Ricardo. (2005). Other People's Money: Debt Denomination and Financial Instability in Emerging Market Economies. Chicago: University of Chicago Press.

Eichengreen, Barry and Irwin, Douglas A. (2010). "The slide to protectionism in the Great Depression: Who succumbed and why?" The Journal of Economic History, 70(4), pp.871-897.

Einzig, Paul. (1932). The Tragedy of the Pound. London: Kegan Paul, Trench, Trubner \& Co.

Flandreau, Marc, and Sussman, Nathan (2005). "Old Sins: Exchange Clauses and European Foreign Lending" in Other People's Money: Debt Denomination and Financial Instability in Emerging Market Economies. Eichengreen, Barry and Hausmann, Ricardo, (eds.) pp. 154-189. Chicago: University of Chicago Press. 
Jacks, David S., Meissner, Christopher M. and Novy, Dennis. (2011). "Trade booms, trade busts, and trade costs". Journal of International Economics, 83(2), pp.185-201.

League of Nations (various years) Statistical year book of the League of Nations. Geneva, Switzerland: League of Nations, Economic and Financial Section.

McCauley, Robert N., McGuire, Patrick, and Sushko, Vladyslav. (2015). "Global dollar credit: links to US monetary policy and leverage." Economic Policy, 30(82), pp. 187-229.

New Zealand. (1932). Report of the Economic Committee. Wellington, NZ: W.A.G.

Skinner, Govt. Printer.

Reinhart, Carmen M. and Rogoff, Kenneth S. (2011). "From Financial Crash to Debt Crisis," American Economic Review, 101(5) pp. 1676-1706.

Simmons, Beth. (1994). Who adjusts? Domestic sources of foreign economic policy during the interwar years. Princeton, N.J.: Princeton University Press.

Stock Exchange Official Intelligence. (1931). London: Spottiswoode, Ballantyne.

United Nations (1948). Public Debt, 1914-1946, Department of Economic Affairs, (Lake Success, New York, 1948: United Nations).

The Economist (various issues).

The New York Times (various issues).

Wandschneider, Kirsten. (2008). "The stability of the interwar gold exchange standard: Did politics matter?" The Journal of Economic History, 68(1), pp.151-181.

Wolf, Nikolaus. (2008). "Scylla and Charybdis: explaining Europe's exit from gold, January 1928-December 1936". Explorations in Economic History, 45(4), pp.383-401.

Wolf, Holger C. and Yousef, Tarik. (2007). "Breaking the fetters: Why did countries exit the interwar Gold Standard?" The New Comparative History: Essays in Honor of Jeffrey G. Williamson, MIT Press, Cambridge, MA, pp.241-65. 


\section{Data Appendix A.1}

\section{Bonds for Event Study, weekly sample}

This table lists the bonds included in the event study of weekly bond yields. We have all listed Dominion, Colonial and Foreign bond yields from the weekly issues of The Economist published between August and October, 1931. The Economist was published on Saturdays and listed bond prices for the previous Wednesday. No information on high-low prices nor for bid-ask spreads is given.

For yields we used the current yield (coupon/price) for all bonds. However, we used the "present yield" given by The Economist for the two French bonds (4\%s and $5 \%$ s) and for Canada's $4 \%$ s. Chile, Turkey, Mexico, and Brazil were in default according to The Economist. We do not use data on bond prices from these countries. To calculate bond spreads, we used the current yield on the British consol.

To determine the currency of denomination or repayment we used the Stock Exchange Official Intelligence for 1931. This source listed the contractual terms for a large number of bond issues for these governments. We were able to locate all of the bonds listed in The Economist in this source. When a bond was contractually payable at an exchange rate favorable to the debtor in a currency including, but not limited to, the pound we labelled this as payable in GBP. Otherwise bonds were payable in other currencies linked to gold.

\section{London Sample}

(The Economist)

\begin{tabular}{|c|c|c|c|c|c|}
\hline Country & Bond Description & Currency & Country & Bond Description & Currency \\
\hline AUS & AUS $5 \%$ 1945-75 & GBP & DNK & Danish $3 \%$ & GOLD \\
\hline CAN & Canada 4\% 1940-60 & GBP & DZG & Danizg $6.5 \%$ & GBP \\
\hline LKA & Ceylon 6\% 1936-51 & GBP & EGY & Egypt Unified $4 \%$ & GBP \\
\hline GHA & Gold Coast $4.5 \% 1956$ & GBP & EST & Estonia $7 \% 1927$ & GBP \\
\hline KEN & Kenya 5\% 1948-58 & GBP & FIN & Finland 6\% 1923 & GOLD \\
\hline NGA & Nigeria $5 \%$ 1950-60 & GBP & FRA & France $4 \%$ (British) & GOLD \\
\hline AUS & NSW 5\% 1935-1955 & GBP & FRA & France $5 \%$ & GOLD \\
\hline NZL & $\begin{array}{l}\text { NZ 5\% } 1946 \\
\text { Queensland 5\% 1940- }\end{array}$ & GBP & DEU & $\begin{array}{l}\text { Germany } 7 \% \\
\text { Germany } 5.5 \% \text { Stg. }\end{array}$ & GBP \\
\hline AUS & $\begin{array}{l}1960 \\
\text { South Africa } 5 \% \text { 1945- }\end{array}$ & GBP & DEU & $\begin{array}{l}\text { Bonds } 1930 \\
\text { Greece } 6 \%\end{array}$ & GBP \\
\hline ZAF & $\begin{array}{l}1975 \\
\text { Straits Settlement } 4.5 \%\end{array}$ & GBP & GRC & Stabilization Loan & GBP \\
\hline SGP & $1935-1945$ & GBP & GRC & Greece $7 \%$ Refugee & GOLD \\
\hline ARG & Argentina $4 \%$ Reciss. & GOLD & HUN & Hungary $7.5 \%$ & GBP \\
\hline
\end{tabular}




\begin{tabular}{|c|c|c|c|c|c|}
\hline AUT & $\begin{array}{l}\text { Austria } 6 \% \text { 1923-1943 } \\
\text { Austria } 7 \% \text { Int. Red. By }\end{array}$ & GBP & JAP & $\begin{array}{l}\text { Japan } 5.5 \% 1935- \\
1965\end{array}$ & GOLD \\
\hline AUT & 1957 & GBP & JAP & Japan 6\% 1924 & GOLD \\
\hline ARG & Buenos Aires Prov. 3.5\% & GOLD & MEX & Mexico 5\% 1899 & GOLD \\
\hline BEL & Belgium $7 \%$ & GOLD & NOR & Norway $4 \% 1911$ & GOLD \\
\hline BGR & Bulgaria $7.5 \%$ Loan & GBP & PER & Peru $7.5 \% 1922$ & GBP \\
\hline BRA & Brazil 5\% Fund, 1914 & GBP & POL & Poland $7 \%$ & GOLD \\
\hline BRA & Brazil 6.5\% 1927 & GOLD & THA & Siam 6\% 1934-64 & GBP \\
\hline CHL & Chili 6\% 1929 & GBP & SWE & $\begin{array}{l}\text { Sweden } 3.5 \% 1908 \\
\text { Sao Paulo Coffee }\end{array}$ & GOLD \\
\hline $\mathrm{CHN}$ & China 5\% 1912 & GBP & BRA & $7.5 \%$ & GOLD \\
\hline $\mathrm{CHN}$ & China 5\% 1913 & GOLD & TUR & Turkey $4 \%$ Unified & GBP \\
\hline $\mathrm{CZE}$ & Czechoslovakia $8 \%$ & GBP & URY & Uruguay 5\% 1919 & GOLD \\
\hline
\end{tabular}

The New York sample of bonds is listed below. All bond prices were from the prices published on Wednesday between 7/29/1931 and 10/28/1931. A range of bond prices was given in the newspaper according to different order volumes. We took the highest bond price available. All debt was payable in 1931 in US dollars and since the dollar was still linked to the gold standard we coded this a payable in "gold".

New York Sample (New York Times)

\begin{tabular}{lll} 
Country & Bond description & Currency \\
\hline AUS & AUS $4.5 \% 1956$ & GOLD \\
AUS & AUS $5 \% 1955$ & GOLD \\
BEL & BEL $6 \% 1955$ & GOLD \\
BEL & BEL $6.5 \% 1949$ & GOLD \\
CAN & CAN $4.5 \% 1936$ & GOLD \\
CAN & CAN $4 \% 1960$ & GOLD \\
CAN & CAN $5 \% 1952$ & GOLD \\
CHN & CHN $5 \% 1951$ & GOLD \\
DNK & DNK $4.5 \% 1962$ & GOLD \\
DNK & DNK $5.5 \% 1953$ & GOLD \\
DNK & DNK $6 \% 1942$ & GOLD \\
FRA & FRA $7 \% 1949$ & GOLD \\
FRA & FRA $7.5 \% 1941$ & GOLD
\end{tabular}




\begin{tabular}{lll} 
JAP & JAP $5.5 \% 1965$ & GOLD \\
JAP & JAP $6.5 \% 1954$ & GOLD \\
SWE & SWE $5.5 \% 1954$ & GOLD \\
\hline
\end{tabular}




\section{Data Appendix A.2}

\section{Bonds and Data for Event Study, daily sample}

This table shows all bonds available in the Financial Times. We used the Stock Exchange Official Intelligence to determine the currency clause for each bond. Daily exchange rates are from Global Financial Data. All bonds from New York (listed in bold) are payable in gold. All Mexican, Honduran, and Turkish bonds are listed as in default in the Stock Exchange Official Intelligence and excluded from the estimating sample.

\begin{tabular}{|c|c|c|c|c|c|}
\hline Country & Bond Description & Currency & Country & Bond Description & Currency \\
\hline \multirow[t]{2}{*}{ ARG } & ARGENTINE $4 \%$ & GBP & & & \\
\hline & RESCISSION & & RUS & RUSSIAN 5\% 1906 & GBP \\
\hline \multirow[t]{2}{*}{ ARG } & ARGENTINE (PORT & GBP & & & \\
\hline & OF CAPITAL) $5 \%$ & & FRA & SEINE 7\% STER. BDS. & GBP \\
\hline \multirow[t]{2}{*}{ ASA } & S. AUSTL. $5 \%$ 1945-75 & GBP & & SALVADOR $6 \%$ & \\
\hline & & & SLV & BONDS & GBP \\
\hline AUS & S. AUSTL. $6 \%$ 1930-40 & GBP & BRA & SN. PAULO $6 \%$ & GBP \\
\hline \multirow[t]{2}{*}{ AUS } & AUS $4.75 \%$ 1940-1960 & GBP & & SN. PAULO COFFEE & \\
\hline & & & BRA & $7 \%$ & GOLD \\
\hline \multirow[t]{2}{*}{ AUS } & AUS 5\% 1935-1945 & GBP & & SN. PAULO COFF & \\
\hline & & & BRA & $7.5 \% \mathrm{BDS}$ & GOLD \\
\hline AUS & AUS 5\% 1945-75 & GBP & STR & STRAITS $4.5 \%$ 1935-45 & GBP \\
\hline AUT & AUSTRIAN $6 \%$ & GBP & AUS & TASMANIA $5 \%$ 1932-42 & GBP \\
\hline AUT & AUSTRIAN 7\% & GBP & THA & SIAM $6 \%$ & GBP \\
\hline BEL & BELGIAN 3\% 1914 & GBP & TUR & TURKISH $4 \%$ UNIFIED & GBP \\
\hline BEL & BELGIAN 7\% & GOLD & GBR & GB Consols 2.5\% & GBP \\
\hline BGR & BULGARIA $7 \%$ & GBP & URY & URUGUAY $3.5 \%$ & GBP \\
\hline \multirow[t]{2}{*}{ BRA } & BRAZILIAN $4 \%$ & GBP & & & \\
\hline & RESCISSION & & URY & URUGUAY $5 \% 1896$ & GBP \\
\hline \multirow[t]{2}{*}{ BRA } & BRAZILIAN 4\% 1910 & GBP & & UN. OF S.A. $5 \%$ 1933- & \\
\hline & & & ZAF & 43 & GBP \\
\hline
\end{tabular}




\begin{tabular}{|c|c|c|c|c|c|}
\hline \multirow[t]{2}{*}{ BRA } & BRAZILIAN 4\% 1911 & \multirow[t]{2}{*}{ GBP } & \multicolumn{3}{|c|}{ UN. OF S.A. $5 \%$ 1945- } \\
\hline & LOAN & & $\mathrm{ZAF}$ & 75 & GBP \\
\hline \multirow[t]{2}{*}{ BRA } & BRAZILIAN 4\% 1889 & GBP & & VICTORIA $4.75 \%$ 1940- & \\
\hline & & & AUS & 60 & GBP \\
\hline BRA & BRAZILIAN 5\% 1903 & GBP & AUS & VICTORIA 5\% 1945-75 & GBP \\
\hline \multirow[t]{2}{*}{ BRA } & BRAZILIAN 5\% 1913 & GBP & & VICTORIA 5.5\% 1930- & \\
\hline & & & AUS & 40 & GBP \\
\hline \multirow[t]{2}{*}{ BRA } & BRAZILIAN 5\% & GBP & & W. AUSTL. 4.5\% 1935- & \\
\hline & FUNDG1914 & & AUS & 65 & GBP \\
\hline BRA & BRAZILIAN 5\% 1895 & GBP & AUS & W. AUSTL. 5\% 1945-75 & GBP \\
\hline \multirow[t]{2}{*}{ BRA } & BRAZILIAN 5\% & GBP & & STHERN RHODESIA & \\
\hline & FUNDING & & ZWE & $5 \%$ & GBP \\
\hline BRA & BRAZILIAN 6.5\% & GOLD & ARG & ARGEN. 6\% 1959 & GOLD \\
\hline CAN & CAN $3.5 \%$ 1930-50 & GBP & AUS & AUSTL $4.5 \% 1956$ & GOLD \\
\hline CAN & CAN 4\% 1940-1960 & GBP & AUS & AUSTL. 5\% 1955 & GOLD \\
\hline ZAF & CAPE 3.5\% 1929-1949 & GBP & AUS & AUSTL. 5\% 1957 & GOLD \\
\hline CHL & CHILEAN 4.5\% 1886 & GBP & AUS & BRISBANE 5\% 1957 & GOLD \\
\hline CHL & CHILEAN 5\% ANN. A & GBP & AUT & AUSTRIA 7\% 1943 & GOLD \\
\hline CHL & CHILEAN 6\% 1928 & GBP & FRA & BORDE'X 6\% 1934 & GOLD \\
\hline CHL & CHILEAN $7.5 \%$ & GBP & BEL & BELGIAN 6\% 1955 & GOLD \\
\hline \multirow[t]{2}{*}{$\mathrm{CHN}$} & CHINESE $4.5 \%$ GOLD & GBP & & & \\
\hline & 1896 & & BEL & BELGIAN 7\% 1955 & GOLD \\
\hline $\mathrm{CHN}$ & CHINESE 5\% 1912 & GBP & BGR & BULG. $7 \% 1967$ & GOLD \\
\hline \multirow[t]{2}{*}{$\mathrm{CHN}$} & CHINESE $5 \%$ & GOLD & & & \\
\hline & pelt'rg.G.I. '13 & & BRA & BRAZIL $6.5 \% 1957$ & GOLD \\
\hline $\mathrm{CHN}$ & CHINESE 5\% 1896 & GBP & BRA & BRAZIL 7.5\% 1952 & GOLD \\
\hline \multirow[t]{2}{*}{$\mathrm{COL}$} & COLOMBIAN $6 \%$ & GBP & & & \\
\hline & 1913 & & CAN & CANADA 5\% 1952 & GOLD \\
\hline
\end{tabular}




\begin{tabular}{|c|c|c|c|c|c|}
\hline \multirow[t]{2}{*}{ CRI } & COSTA RICA $5 \%$ & \multirow[t]{2}{*}{ GOLD } & \multirow[b]{2}{*}{ CHE } & \multirow[b]{2}{*}{ SWISS 5.5\% 1945} & \multirow[b]{2}{*}{ GOLD } \\
\hline & 1911 & & & & \\
\hline \multirow[t]{2}{*}{$\mathrm{CZE}$} & CZECHOSLOVAKIA & GBP & & & \\
\hline & $8 \%$ & & CHL & CHILE 6\% 1961 & GOLD \\
\hline \multirow[t]{2}{*}{ IDN } & DUTCH EAST & GBP & & & \\
\hline & INDIES $5 \%$ & & CHL & CHILE 7\% 1942 & GOLD \\
\hline \multirow[t]{2}{*}{ IDN } & DUTCH EAST & GBP & & COLOMBIAN 6\% & \\
\hline & INDIES $6 \%$ & & COL & 1961 & GOLD \\
\hline \multirow[t]{2}{*}{ DEU } & GERMAN $5.5 \%$ & GBP & & CZECHOSLOVAKIA & \\
\hline & & & $\mathrm{CZE}$ & $8 \% 1951$ & GOLD \\
\hline DEU & GERMAN 7\% & GBP & CUB & CUBA $5.5 \% 1953$ & GOLD \\
\hline \multirow[t]{2}{*}{$\mathrm{DEU}$} & POTASH SYND. OF & GOLD & & DUTCH EAST & \\
\hline & GERM. $7 \%$ & & IDN & INDIES $5.5 \% 1953$ & GOLD \\
\hline \multirow[t]{2}{*}{ DEU } & WESTPHALIA 7\% & GBP & & DUTCH EAST & \\
\hline & & & IDN & INDIES 6\% 1962 & GOLD \\
\hline \multirow[t]{2}{*}{ DZG } & DANZIG 7\% & GBP & & GERMAN $5.5 \%$ & \\
\hline & & & DEU & INT. 1965 & GOLD \\
\hline \multirow[t]{2}{*}{ EGY } & EGYPTIAN UNIFIED & GBP & & & \\
\hline & $4 \%$ & & DEU & GERMAN 7\% 1949 & GOLD \\
\hline \multirow[t]{2}{*}{ ESP } & SPANISH $4 \%$ & GOLD & & HEIDLBERG $7.5 \%$ & \\
\hline & & & DEU & 1950 & GOLD \\
\hline \multirow[t]{2}{*}{ FIN } & FINLAND $6 \%$ & GBP & & DENMARK 5.5\% & \\
\hline & & & DNK & 1955 & GOLD \\
\hline \multirow[t]{2}{*}{ FRA } & FRENCH WAR & GOLD & & & \\
\hline & LOAN $4 \%$ (brit. Iss.) & & FIN & FINLAND 6\% 1945 & GOLD \\
\hline \multirow[t]{2}{*}{ FRA } & FRENCH WAR & GOLD & & & \\
\hline & LOAN $5 \%$ & & FIN & FIN. MN. 6.5\% 1954 & GOLD \\
\hline \multirow[t]{2}{*}{ GRC } & GREEK 4\% & GBP & & & \\
\hline & MONOPOLY & & FRA & FRENCH 7\% 1949 & GOLD \\
\hline GRC & GREEK 6\% BONDS & GBP & FRA & FRENCH $7.5 \% 1941$ & GOLD \\
\hline
\end{tabular}




\begin{tabular}{|c|c|c|c|c|c|}
\hline GRC & GREEK $7 \%$ & GBP & GRC & GREEK 6\% 1968 & GOLD \\
\hline GTM & GUATEMALA $4 \%$ & GBP & GRC & GREEK 7\% 1964 & GOLD \\
\hline HND & HONDURAS & GBP & HTI & HAITI $6 \% 1952$ & GOLD \\
\hline \multirow[t]{2}{*}{ HUN } & HUNGARIAN 7.5\% & GBP & & HUNGARY $7.5 \%$ & \\
\hline & & & HUN & 1944 & GOLD \\
\hline \multirow[t]{2}{*}{ HUN } & HUNGARY & GBP & & IRISH FREE STATE & \\
\hline & $\left(\mathrm{C}^{\prime} \mathrm{NTIES}\right) 7.5 \%$ & & IRL & $5 \% 1960$ & GOLD \\
\hline \multirow[t]{2}{*}{ IRL } & IRISH FREE STATE & GBP & & & \\
\hline & 4.5\% LAND BONDS & & ITA & ROME $6.5 \% 1952$ & GOLD \\
\hline \multirow[t]{2}{*}{ ITA } & ITALIAN RENTES & GBP & & & \\
\hline & $3.5 \%$ & & ITA & ITALIAN 7\% 1951 & GOLD \\
\hline JAM & JAM 4.5\% 1941-1971 & GBP & JPN & TOKYO 5.5\% 1961 & GOLD \\
\hline JPN & JAPAN 4\% 1910 & GBP & JPN & JAPAN $5.5 \% 1965$ & GOLD \\
\hline JPN & JAPAN 4\% 1899 & GBP & JPN & JAPAN 6.5\% 1954 & GOLD \\
\hline \multirow[t]{2}{*}{ JPN } & JAPAN 5\% 1907 & GBP & & NORWAY $5.5 \%$ & \\
\hline & & & NOR & 1965 & GOLD \\
\hline JPN & JAPAN $5.5 \%$ CONV. & GOLD & NOR & NORWAY 6\% 1944 & GOLD \\
\hline \multirow[t]{2}{*}{ JPN } & JAPAN (TOKYO) & GBP & & & \\
\hline & $5.5 \%$ & & NOR & NORWAY 6\% 1952 & GOLD \\
\hline JPN & JAPAN 6\% 1924 & GBP & PER & PERU 6\% 1961 & GOLD \\
\hline LKA & CEYLON 6\% 1936-51 & GBP & PER & PERU 7\% 1959 & GOLD \\
\hline MEX & MEXICAN 5\% 1899 & GOLD & POL & POLAND 6\% 1940 & GOLD \\
\hline \multirow[t]{2}{*}{ MEX } & MEXICAN $6 \%$ & GOLD & & & \\
\hline & TREAS. BDS. & & POL & POLAND 7\% 1947 & GOLD \\
\hline NGA & NIGERIA 4\% 1963 & GBP & POL & POLAND 8\% 1950 & GOLD \\
\hline AUS & N.S.W. 3\% 1935 & GBP & DEU & PRUSSIA $6.5 \% 1951$ & GOLD \\
\hline AUS & N.S.W. $4.5 \%$ 1935-45 & GBP & AUS & QUEENSL. 7\% 1941 & GOLD \\
\hline AUS & N.S.W. $5 \%$ 1945-65 & GBP & $\mathrm{RDS}$ & R.DO SUL. 8\% 1946 & GOLD \\
\hline
\end{tabular}




\begin{tabular}{|c|c|c|c|c|c|}
\hline \multirow[t]{2}{*}{ AUS } & \multirow[t]{2}{*}{ N.S.W. $5.25 \%$ 1935-45 } & \multirow[t]{2}{*}{ GBP } & \multicolumn{3}{|c|}{ RUMANIAN $7 \%$} \\
\hline & & & ROU & 1959 & GOLD \\
\hline NZL & N.Z. $3.5 \% 1940$ & GBP & FRA & SEINE $7 \% 1942$ & GOLD \\
\hline NZL & N.Z. $4.5 \%$ 1948-58 & GBP & BRA & S. PAULO 6\% 1968 & GOLD \\
\hline NZL & N.Z. $5 \% 1946$ & GBP & BRA & S. PAULO 8\% 1950 & GOLD \\
\hline \multirow[t]{2}{*}{ PER } & PERUVIAN CORP. & & & SAX. P. W. $6.5 \%$ & \\
\hline & 5\% DEBENTURES & & DEU & 1951 & GOLD \\
\hline \multirow[t]{2}{*}{ PER } & PERUVIAN CORP. & & & & \\
\hline & $5 \%$ ORDINARY & & DEU & SAX.P.W. 7\% 1945 & GOLD \\
\hline \multirow[t]{2}{*}{ PER } & PERUVIAN CORP. & & & & \\
\hline & $5 \% \mathrm{PF}$ & & SRB & SERB. 7\% 1962 & GOLD \\
\hline \multirow[t]{2}{*}{ PER } & PERUVIAN GOVT & GOLD & & & \\
\hline & $6 \%$ & & SRB & SERB. 8\% 1962 & GOLD \\
\hline \multirow[t]{2}{*}{ PER } & PERUVIAN GOVT. & GBP & & & \\
\hline & $7.5 \%($ GUANO $)$ & & SWE & SWEDEN 5.5\% 1954 & GOLD \\
\hline POL & POLAND (1927) $7 \%$ & GOLD & GB & U.K. $5.5 \% 1937$ & GOLD \\
\hline \multirow[t]{2}{*}{ POR } & PORTUGUESE $3 \%$ & GBP & & & \\
\hline & $(1 \mathrm{st}$ srs $)$ & & GB & U.K. FUND. $4 \%$ & GOLD \\
\hline \multirow[t]{2}{*}{ POR } & PORTUGUESE 3\% & GBP & & & \\
\hline & (3RD SERIES) & & GB & U.K. $5 \%$ WARLN & GOLD \\
\hline \multirow[t]{2}{*}{ AUS } & QU'NSLAND 5\% 1940- & GBP & & & \\
\hline & 60 & & URY & URUGUAY 6\% 1960 & GOLD \\
\hline \multirow[t]{2}{*}{$\mathrm{ROU}$} & RUMANIAN EX. $4 \%$ & GBP & & US. LIB. LOAN $3.5 \%$ & \\
\hline & 1922 & & USA & 1932-1947 & GOLD \\
\hline \multirow[t]{2}{*}{$\mathrm{ROU}$} & RUMANIAN $4 \%$ & GBP & & & \\
\hline & CONS & & USA & U.S. $3.75 \%$ T. BDS & GOLD \\
\hline \multirow[t]{3}{*}{ ROU } & RUMANIAN 7\% & GOLD & & U.S. LIB. LOAN & \\
\hline & & & & $4 \mathrm{TH} 4.25 \%$ 1933- & \\
\hline & & & USA & 1938 & GOLD \\
\hline
\end{tabular}




\section{Appendix B Sovereign Default}

Here we provide a list of countries in default in the period. Note that we classify non-payment of allied war debts or reparations as default.

Table B1 Countries that Defaulted After Going off the Gold Standard

\begin{tabular}{lccc} 
Country & Year Default & Year off Gold & Difference \\
\hline Austria & 1932 & 1931 & 1 \\
Brazil & 1931 & 1930 & 1 \\
Bulgaria & 1932 & 1931 & 1 \\
Czechoslovakia & 1932 & 1931 & 1 \\
Germany & 1932 & 1931 & 1 \\
Greece & 1932 & 1931 & 1 \\
Hungary & 1932 & 1931 & 1 \\
Paraguay & 1932 & 1929 & 3 \\
Turkey & 1928 & 1915 & 13 \\
United Kingdom & 1933 & 1931 & 2 \\
Uruguay & 1933 & 1929 & 4 \\
\hline Average Difference (w/o Turkey) & & 1.6
\end{tabular}

Table B2 Countries that Defaulted Before Going off the Gold Standard

\begin{tabular}{lccc} 
Country & Year Default & Year off Gold & Difference \\
\hline Belgium & 1932 & 1935 & 3 \\
Cuba & 1933 & 1934 & 1 \\
Ecuador & 1929 & 1932 & 3 \\
France & 1932 & 1936 & 4 \\
Italy & 1932 & 1936 & 4 \\
Mexico & 1928 & 1931 & 3 \\
Panama & 1932 & 1933 & 1 \\
Peru & 1931 & 1932 & 1 \\
Poland & 1932 & 1936 & 4 \\
\hline Average Difference & & &
\end{tabular}


Table B3 Countries that Defaulted in the Same Year as Going off the Gold Standard

\begin{tabular}{lcc} 
Country & Year Default & Year off Gold \\
\hline Bolivia & 1931 & 1931 \\
Chile & 1931 & 1931 \\
Colombia & 1932 & 1932 \\
Costa Rica & 1932 & 1932 \\
Guatemala & 1933 & 1933 \\
Nicaragua & 1932 & 1932 \\
Romania & 1932 & 1932 \\
United States & 1933 & 1933
\end{tabular}

Table B4 Countries that did not Default but did Go off Gold

\begin{tabular}{lclclc} 
Country & Year off Gold & Country & Year off Gold & Country & Year off Gold \\
\hline Argentina & 1929 & Malaysia & 1931 & Thailand & 1932 \\
Australia & 1930 & Netherlands & 1936 & Venezuela & 1930 \\
Canada & 1931 & New Zealand & 1932 & Danzig & 1935 \\
Denmark & 1931 & Norway & 1931 & El Salvador & 1931 \\
Egypt & 1931 & Philippines & 1933 & Estonia & 1933 \\
Finland & 1931 & Portugal & 1931 & Latvia & 1936 \\
Honduras & 1933 & Salvador & 1931 & Luxembourg & 1935 \\
India & 1931 & South Africa & 1932 & Palestine & 1931 \\
Indonesia & 1936 & Spain & 1920 & Yugoslavia & 1932 \\
Ireland & 1931 & Sweden & 1931 & & \\
Japan & 1932 & Switzerland & 1936 & & \\
\hline
\end{tabular}


Figure 1 Average Ratio of Foreign Public Debt to Exports for 33 Countries, 1928

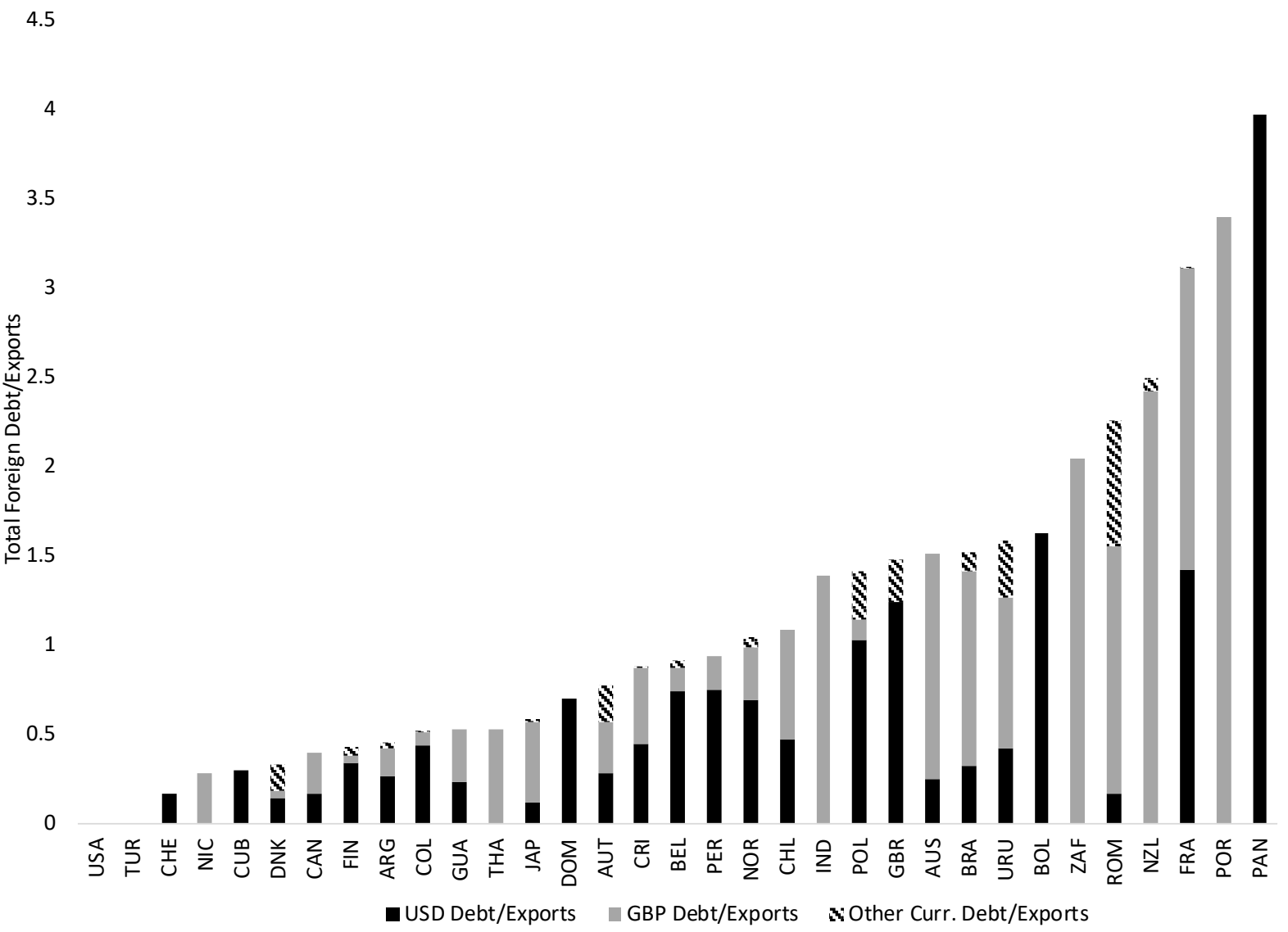

Notes: Data are from United Nations (1948). See text for a description of data. 
Figure 2 The Impact of Exchange Rate Depreciation on Foreign Debt for Denmark, 1928-1934.

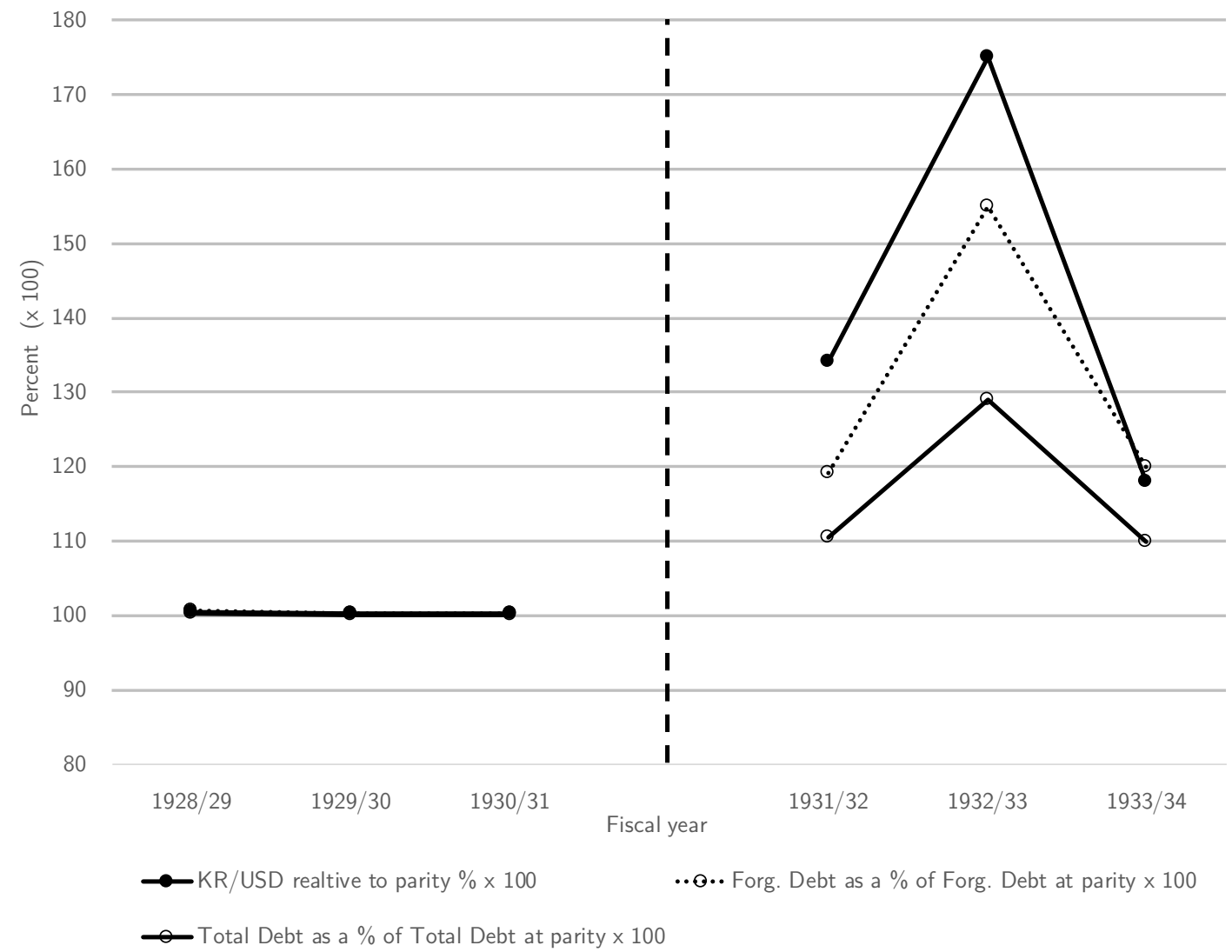

Notes: Figure shows the impact of the depreciation of the kronor on the value of Danish debt in kronor. Data are from United Nations (1948). KR/USD is the exchange rate of the Danish crown versus the US dollar. Foreign Debt and total debt at current exchange rates and at a fixed exchange rate was calculated by the United Nations (1948). 
Figure 3 The Impact of Exchange Rate Depreciation on Foreign Currency Debt for Norway, 19281940.

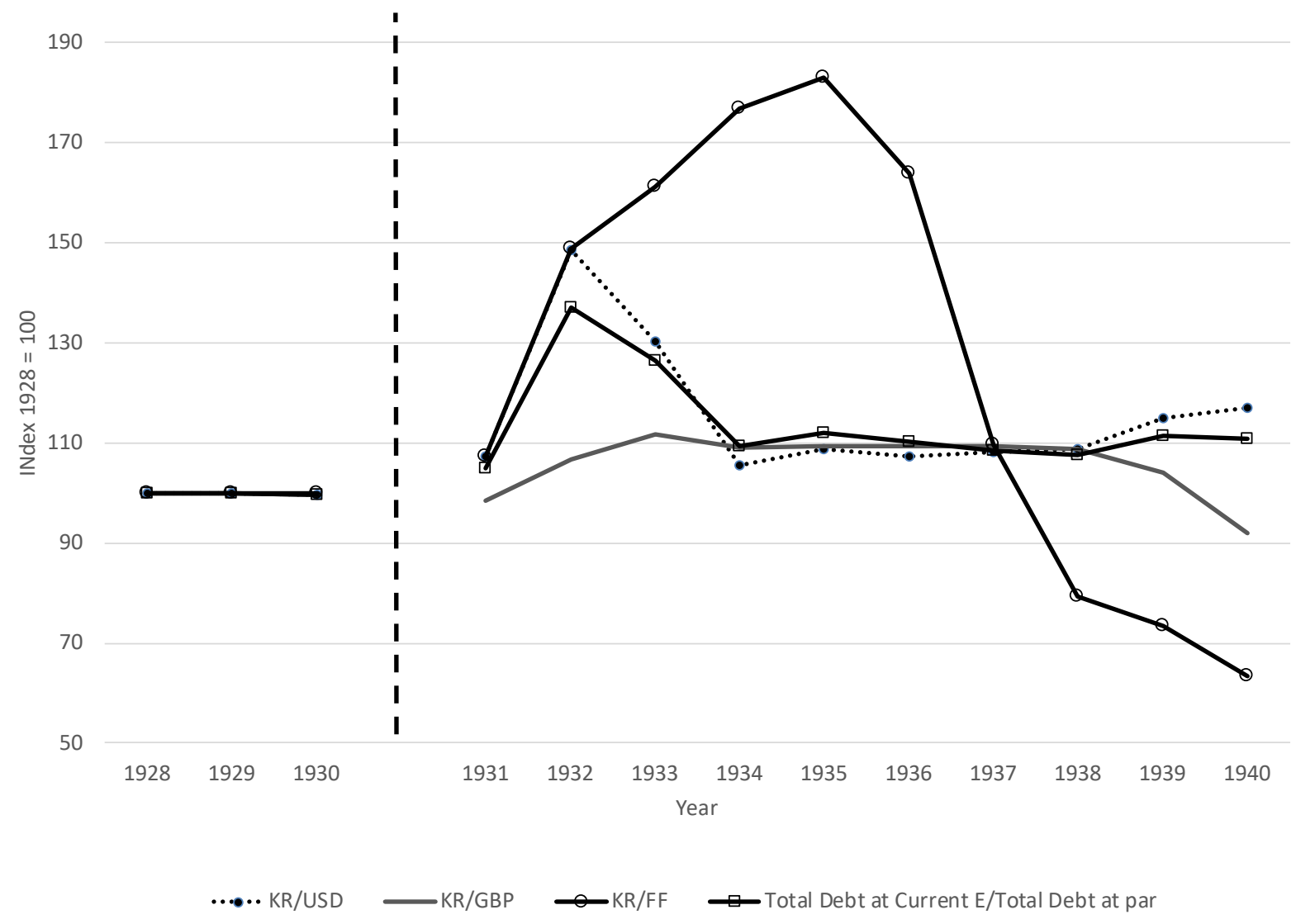

Notes: Figure shows the impact of the depreciation of the kronor on the value of Norwegian debt measured in kronor. Data are from United Nations (1948). KR/USD is the exchange rate of the Norwegian crown (kronor) versus the US dollar. Foreign debt in foreign currency and at par exchange rates in kronor is given in the United Nations (1948). We use only the debt issued in GBP, US dollars and French francs. We use exchange rates from David S. Jacks (personal communication) to convert foreign currency to kronor at current exchange rates. 
Figure 4 The Impact of Exchange Rate Depreciation on Foreign Currency Debt for Chile, 19281940.

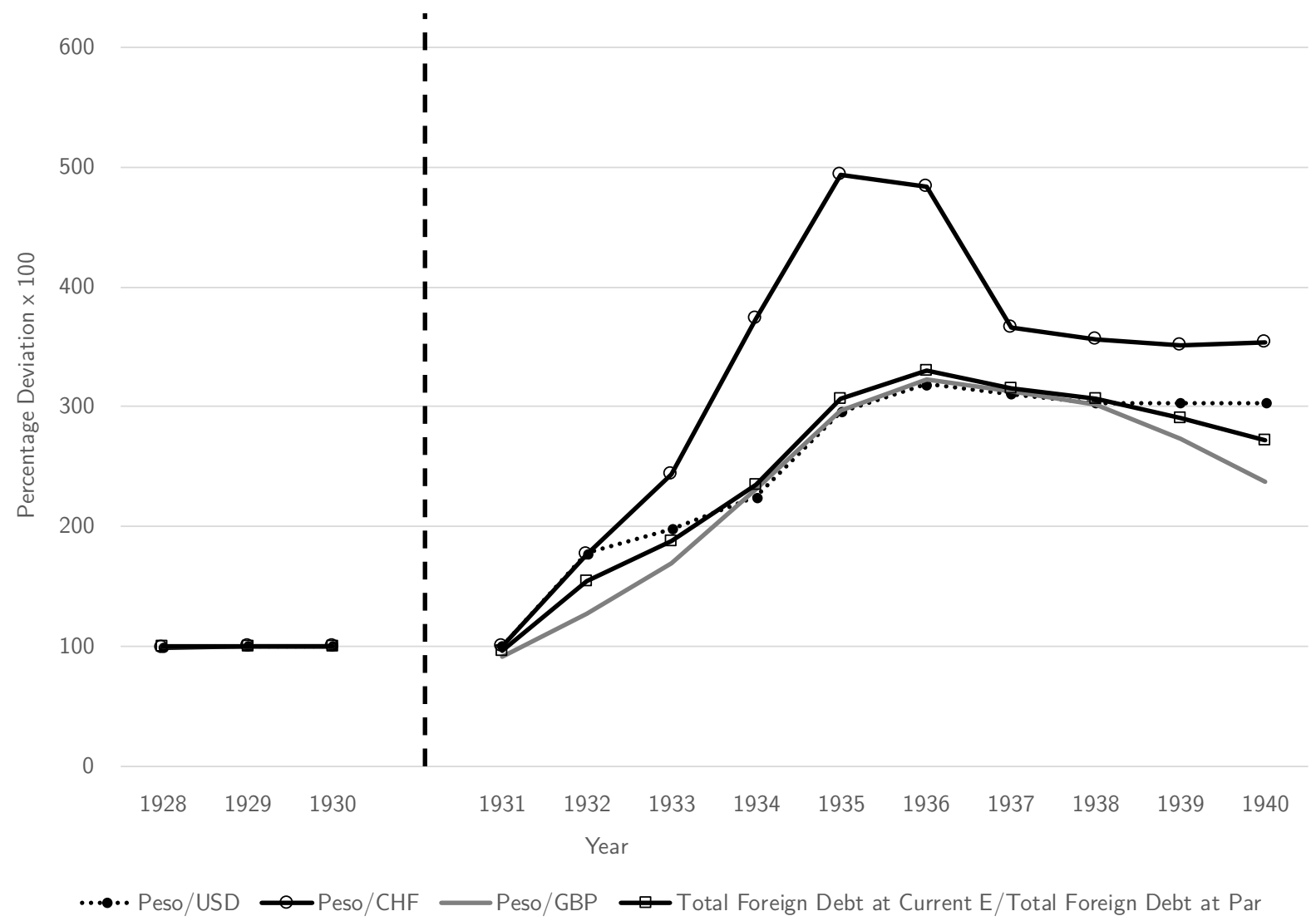

Notes: Figure shows the impact of the depreciation of the peso on the value of Chilean debt measured in pesos. Data are from United Nations (1948). Peso/USD is the exchange rate of the Norwegian crown (kronor) versus the US dollar. CHF is the Swiss franc, and GBP is pounds sterling. Foreign debt in foreign currency is given in the United Nations (1948). Debt was issued in US dollars, pounds sterling and in Swiss francs. We use exchange rates from David S. Jacks (personal communication) to convert foreign currency to kronor at current exchange rates and at par. Par exchange rates are given in United Nations and are equal to those prevailing in 1928. 
Figure 5 Bond Spreads, Gold Clauses and Exchange Rate Policies, Weekly Data

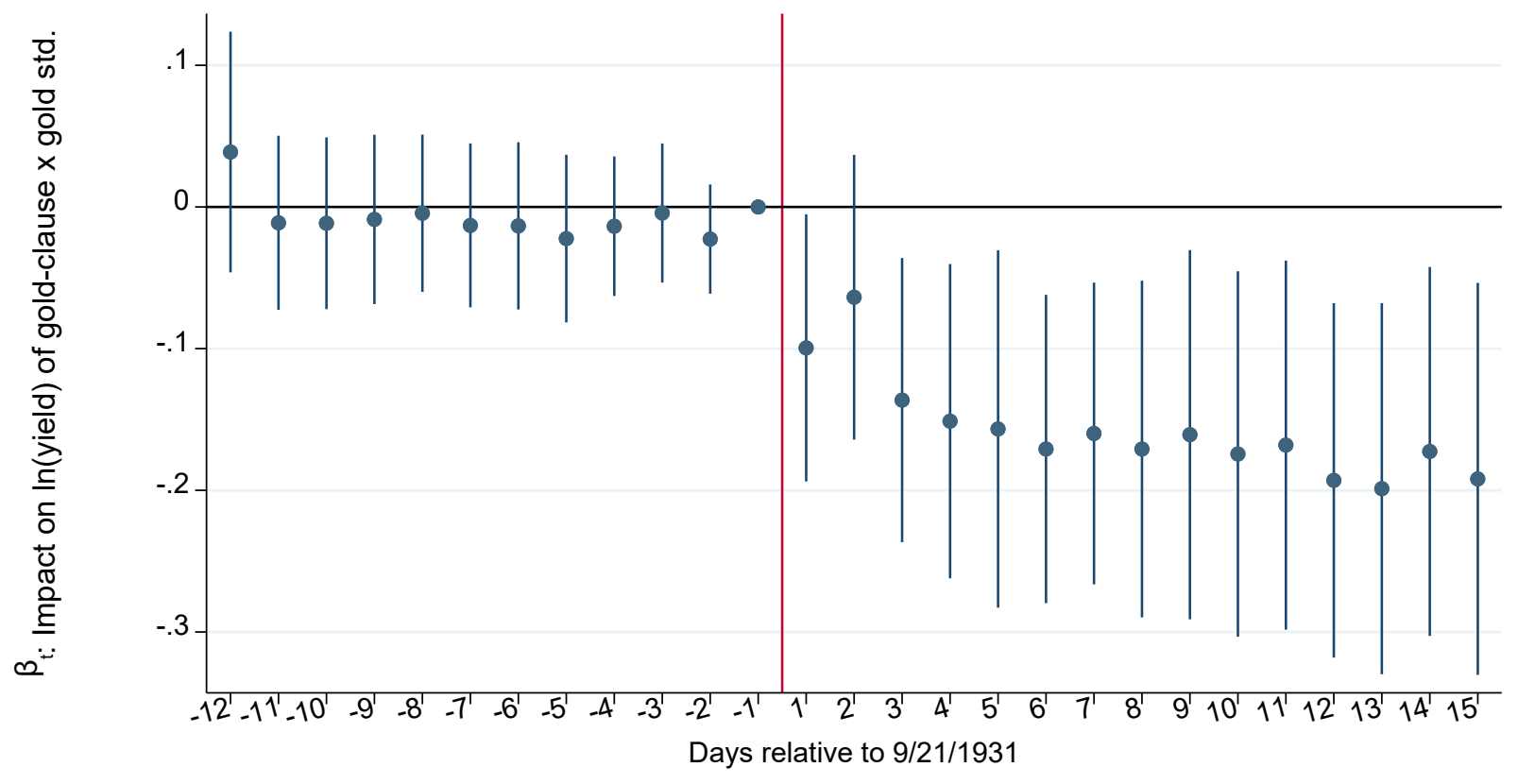

Notes: Figures show the coefficients on the gold clause-gold standard indicator each day week before and after $9 / 21 / 1931$. The day $9 / 21 / 1931$, the event date, is omitted from the sample and $9 / 19 / 1931$ is a reference category. The dependent variable is the log of the bond yield, and included controls are those in Table 3. Standard errors are clustered at the country level. 95\% confidence bands are shown. 
Figure 6 Simulation of the Benassy-Quere Model with Different Trade and Debt Shares

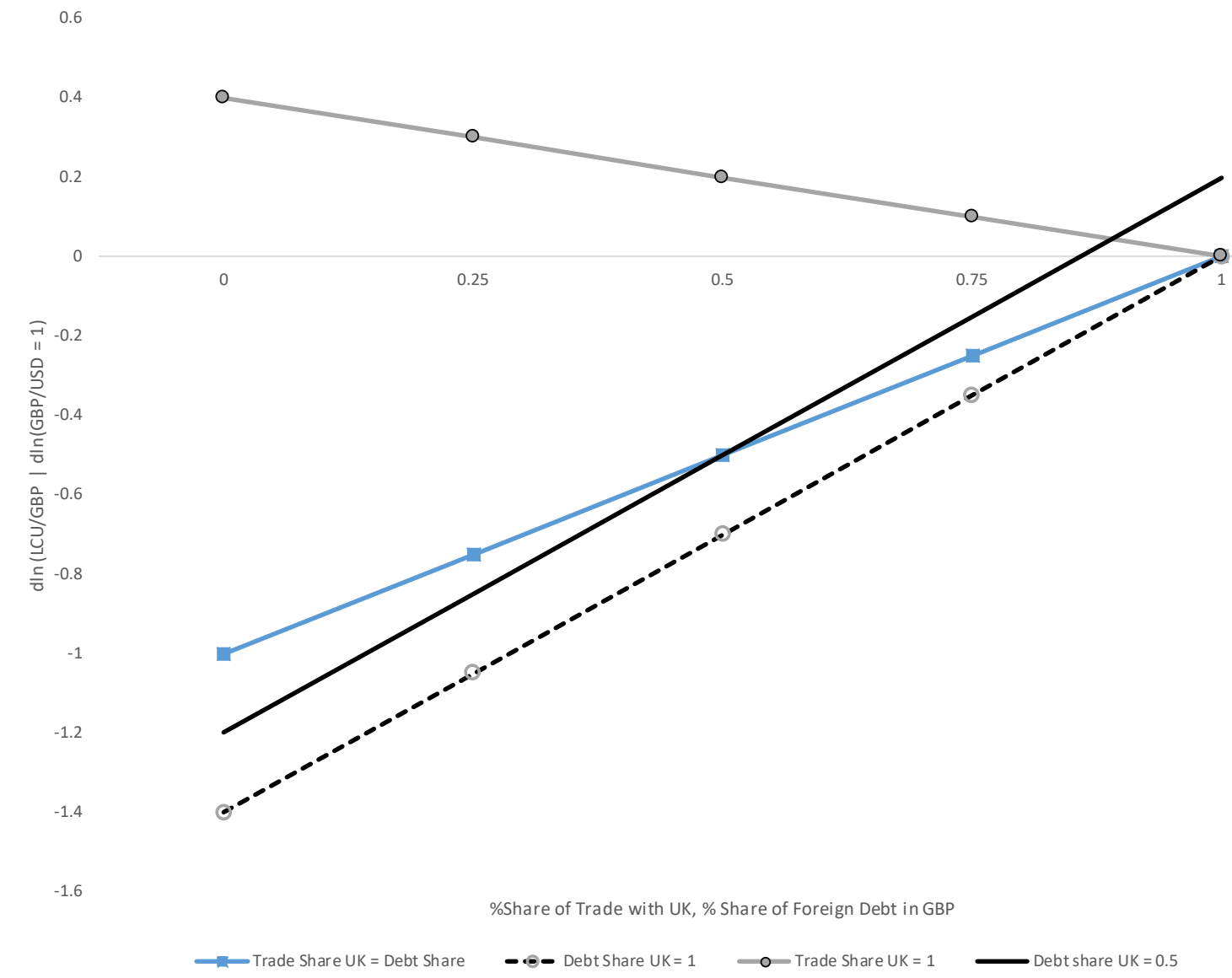

Notes: Graph shows predicted exchange rate change against the pound for the model explored in Section 4. The model is parameterized as per the text. Each line holds either the share of debt denominated in GBP or the share of trade with Great Britain constant while allowing the other share to vary along the x-axis. One line labelled (Trade Share UK = Debt Share) allows both shares to move together between 0 and 1 . The y-axis shows the predicted change of the local currency against the pound in percentage terms (x 100) for a 1 percent depreciation of sterling against the dollar. Negative values are appreciations against the pound. A movement of 0 against sterling is a peg to sterling. 
Figure 7 Change in the USD Exchange Rate against the Policy Rule

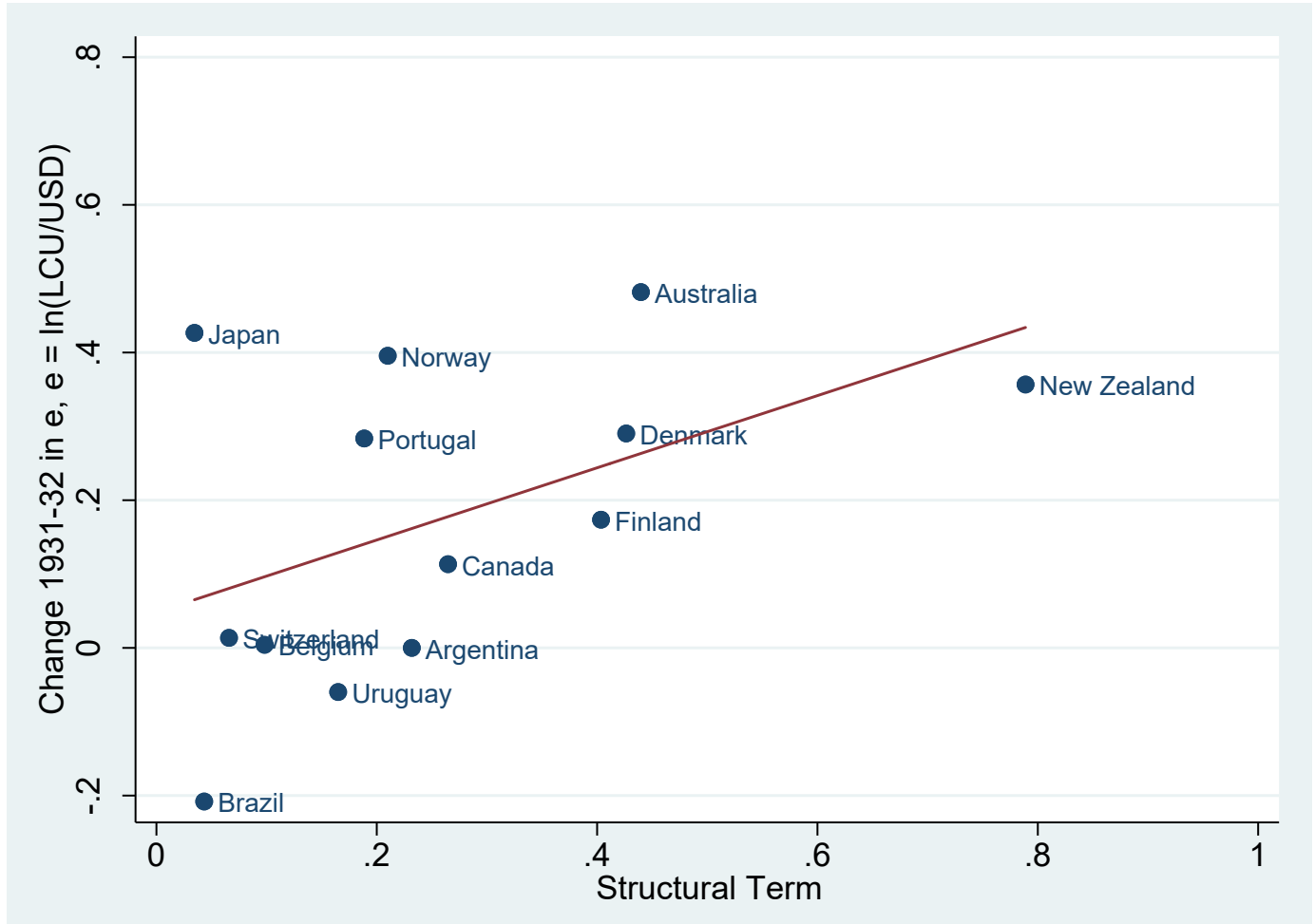

Notes: This chart shows the bivariate OLS regression of the change in the (log of) the US dollar exchange rate (local currency per US dollar) against the policy rule from the theoretical model described above and a constant. The policy rule is a function of the trade share, trade elasticities, debt shares etc. See the text for a description. 
Figure 8 Change in the GBP Exchange Rate against the Policy Rule

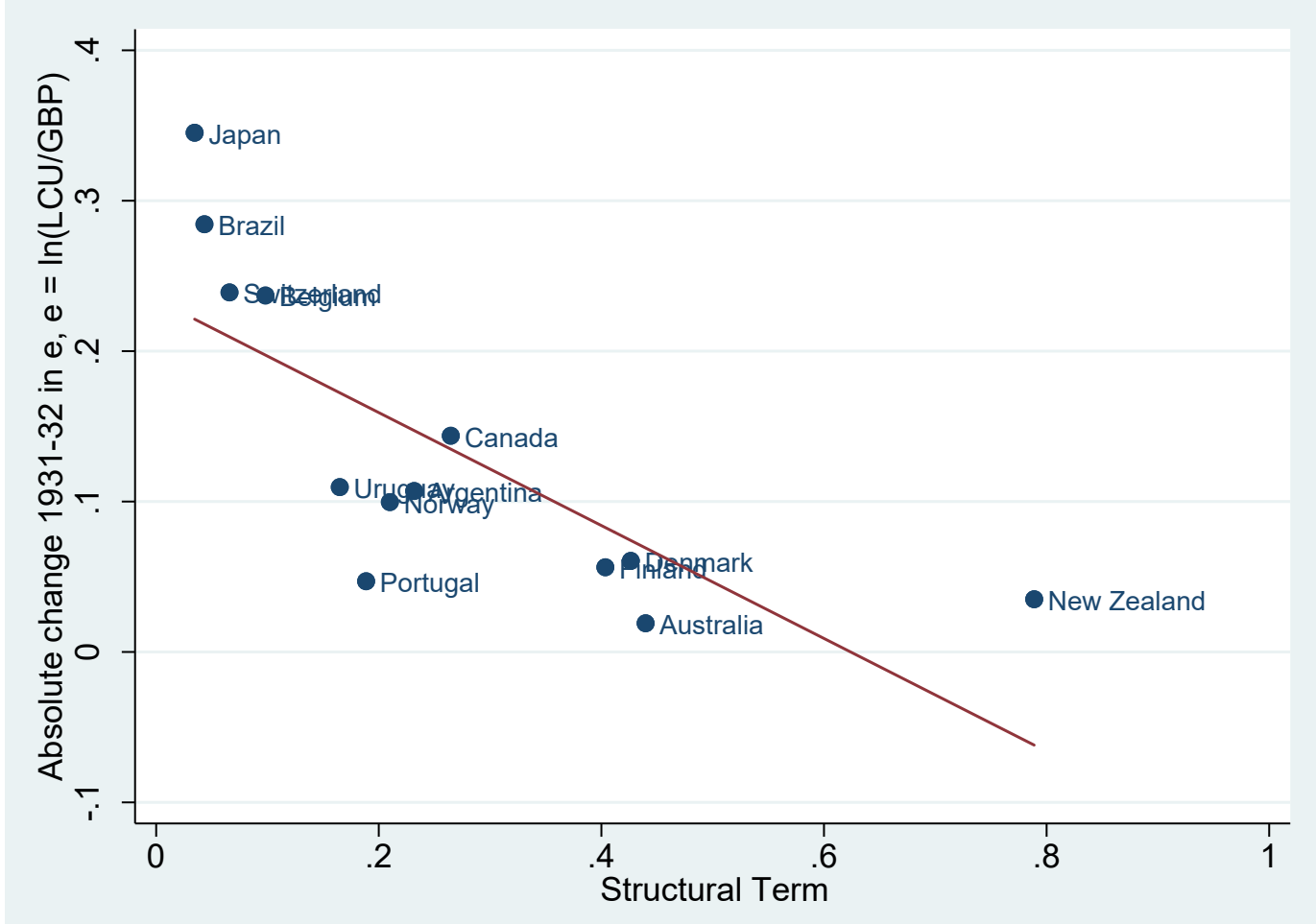

Notes: This chart shows the bivariate OLS regression of the absolute value of the change in the GBP exchange rate (local currency per GBP) against the policy rule from the theoretical model described above and a constant. The policy rule is a function of the trade share, trade elasticities, debt shares etc. See the text for a description. 
Figure 9 Change in Absolute Value of the Nominal Exchange Rate against GBP or USD versus Foreign Currency Debt

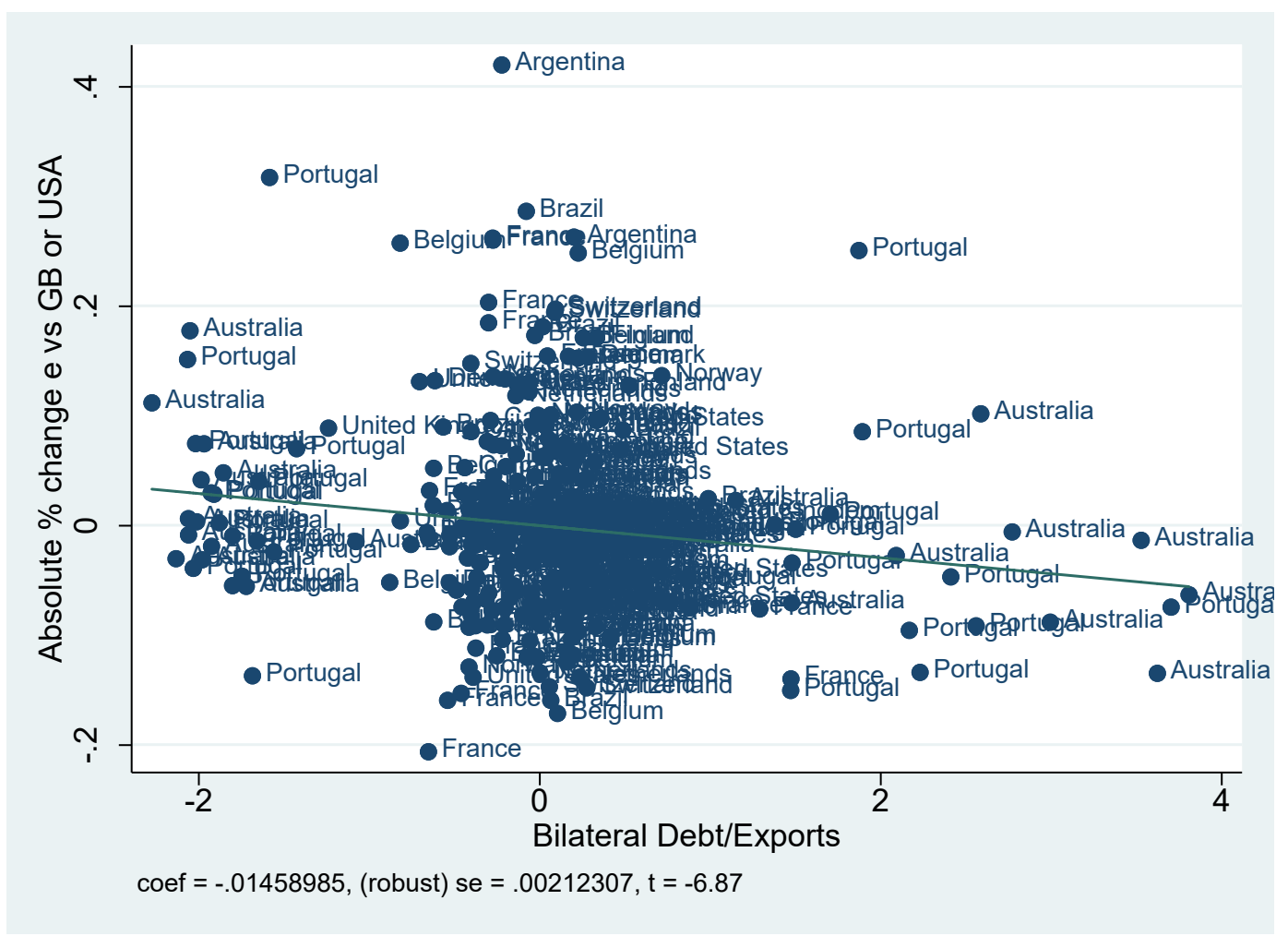

Notes: This figure shows the bivariate relationship between the currency denomination of debt and the exchange rate. The model is estimated by OLS, and includes all controls of the models in Table 4. 
Table 1 Bond Prices as a Function of Currency Denomination of Debt and Exchange Rate Policy

\begin{tabular}{|c|c|c|}
\hline & Peg to pound & Peg to Gold \\
\hline Bond payable in sterling only & $\begin{array}{l}\text { FX channel: Default risk -no } \\
\text { change. Yield -no change. } \\
\text { Macro channel: devaluation } \\
\text { from gold parity - lower } \\
\text { revenue risk. Yield - fall } \\
\text { Market effect: rise in sale of } \\
\text { sterling bonds, increased } \\
\text { demand for gold debt. Yield - } \\
\text { rise }\end{array}$ & $\begin{array}{l}\text { FX channel: Default risk } \\
\text { lower, lowest among all } \\
\text { entries. Yield - fall } \\
\text { Macro channel: higher risk. } \\
\text { Yield - rise } \\
\text { Market effect: rise in sales of } \\
\text { sterling bonds, increased } \\
\text { demand for gold bonds Yield } \\
\text { - rise }\end{array}$ \\
\hline Payable in USD/FF/GOLD & $\begin{array}{l}\text { FX channel: Default risk } \\
\text { higher than before and highest } \\
\text { among all } 4 \text { entries. Yield- } \\
\text { rise } \\
\text { Macro channel: devaluation } \\
\text { is good for the economy. Yield } \\
\text { - fall } \\
\text { Market effect: Increased } \\
\text { demand for these bonds to } \\
\text { earn gold coupons. Yield - fall }\end{array}$ & $\begin{array}{l}\text { FX channel: A) Default risk } \\
\text { no change, same as entry } \\
(1,1) \text {. Yield - no change. B) } \\
\text { Some risk country will go off } \\
\text { gold. Yield- rise } \\
\text { Macro channel: higher risk, } \\
\text { chance of improvement Yield } \\
\text { - rise } \\
\text { Market effect: Yield - fall }\end{array}$ \\
\hline
\end{tabular}

Notes: This table considers the currency denomination of a sovereign bond and the exchange rate policy for a country. The matrix explores three potential channels for each denomination-policy combination. "Yield" refers to the bond yield. We use the simple current yield (Coupon divided by price) to measure yields. 
Table 2 Event Study of Bond Yields and the Sterling Devaluation, Weekly data

\begin{tabular}{|c|c|c|c|c|}
\hline & Lon & rket Only & \multicolumn{2}{|c|}{ London and New York } \\
\hline & (1) & $(2)$ & $(3)$ & (4) \\
\hline Gold Clause $\mathrm{x}$ Gold peg x post & $\begin{array}{c}-0.12^{* * *} \\
{[0.03]}\end{array}$ & $\begin{array}{c}-0.10^{* *} \\
{[0.04]}\end{array}$ & $\begin{array}{c}-0.12^{* * *} \\
{[0.03]}\end{array}$ & $\begin{array}{c}-0.09^{* *} \\
{[0.03]}\end{array}$ \\
\hline Gold Clause $\mathrm{x}$ Sterling peg $\mathrm{x}$ post & $\begin{array}{c}0.05 \\
\lceil 0.03\rceil\end{array}$ & $\begin{array}{l}0.07^{*} \\
{[0.04]}\end{array}$ & $\begin{array}{c}0.13^{* *} \\
\lceil 0.05\rceil\end{array}$ & $\begin{array}{c}0.16^{* * *} \\
\lceil 0.05\rceil\end{array}$ \\
\hline Gold peg x post & $\begin{array}{c}0.02 \\
\lceil 0.03\rceil\end{array}$ & $\begin{array}{c}0.00 \\
\lceil 0.03\rceil\end{array}$ & $\begin{array}{c}0.02 \\
\lceil 0.03\rceil\end{array}$ & $\begin{array}{c}0.00 \\
\lceil 0.03\rceil\end{array}$ \\
\hline Sterling peg $\mathrm{x}$ post & $\begin{array}{c}-0.08^{* * *} \\
{[0.02\rceil}\end{array}$ & $\begin{array}{c}-0.10^{* * *} \\
{[0.02\rceil}\end{array}$ & $\begin{array}{c}-0.07 * * * \\
{[0.02]}\end{array}$ & $\begin{array}{c}-0.10^{* * *} \\
{[0.02\rceil}\end{array}$ \\
\hline Gold Clause $\mathrm{x}$ post & & $\begin{array}{l}-0.03 \\
\lceil 0.03\rceil\end{array}$ & & $\begin{array}{l}-0.04 \\
\lceil 0.03\rceil\end{array}$ \\
\hline New York market $\mathrm{x}$ post & & & $\begin{array}{l}0.05^{*} \\
\lceil 0.03\rceil\end{array}$ & $\begin{array}{c}0.07^{* *} \\
\lceil 0.03\rceil\end{array}$ \\
\hline Observations & 556 & 556 & 763 & 763 \\
\hline $\mathrm{R}^{2}$ & 0.55 & 0.55 & 0.59 & 0.60 \\
\hline Number of Bonds & 41 & 41 & 56 & 56 \\
\hline Number of Countries & 31 & 31 & 31 & 31 \\
\hline
\end{tabular}

Notes: Regressions are by OLS. The dependent variable is the log of the current yield of a number of bonds. We include fixed effects for each bond and date fixed effects. The sample is each Wednesday between 7/29/1931 and 10/28/1931. Each bond is identified with a currency of repayment and a country/colony. Robust, standard errors clustered at the country level are in brackets. ${ }^{* * *}$ p-value $<0.01 ; * *$ p-value $<0.05{ }^{*}$ p-value $<0.10$. 
Table 3 Event Study of Bond Yields and the Sterling Devaluation, Daily data

\begin{tabular}{|c|c|c|c|}
\hline & \multirow{2}{*}{$\begin{array}{c}\text { London Market Only } \\
(1)\end{array}$} & \multicolumn{2}{|c|}{$\begin{array}{c}\text { London and New York } \\
\text { Markets }\end{array}$} \\
\hline & & $(2)$ & $(3)$ \\
\hline \multirow{2}{*}{ Gold Clause x Gold peg x post } & $-0.13^{* *}$ & $-0.13^{* *}$ & $-0.09^{* *}$ \\
\hline & $\lceil 0.06\rceil$ & $\lceil 0.05\rceil$ & $\lceil 0.04\rceil$ \\
\hline \multirow[t]{2}{*}{ Gold Clause x Sterling peg x post } & --- & 0.04 & 0.07 \\
\hline & & $\lceil 0.07\rceil$ & $\lceil 0.07\rceil$ \\
\hline \multirow[t]{2}{*}{ Gold peg x post } & 0.02 & 0.02 & 0.00 \\
\hline & $\lceil 0.03\rceil$ & $\lceil 0.03\rceil$ & $\lceil 0.03\rceil$ \\
\hline \multirow[t]{2}{*}{ Sterling peg $\mathrm{x}$ post } & $-0.06^{* * *}$ & $-0.06^{* *}$ & $-0.08 * * *$ \\
\hline & $\lceil 0.02\rceil$ & $\lceil 0.03\rceil$ & $\lceil 0.03\rceil$ \\
\hline \multirow[t]{2}{*}{ Gold Clause x post } & --- & & $-0.07 * *$ \\
\hline & & & {$[0.03]$} \\
\hline \multirow[t]{2}{*}{ New York market $\mathrm{x}$ post } & --- & $0.20^{* * *}$ & $0.23^{* * *}$ \\
\hline & & $\lceil 0.04\rceil$ & $\lceil 0.05\rceil$ \\
\hline Observations & 2,562 & 4,191 & 4,191 \\
\hline $\mathrm{R}^{2}$ & 0.42 & 0.46 & 0.46 \\
\hline Number of Bonds & 96 & 160 & 160 \\
\hline Number of Countries & 37 & 45 & 45 \\
\hline
\end{tabular}

Notes: Regressions are by OLS. The dependent variable is the log of the current yield of a number of bonds. We include fixed effects for each bond and date fixed effects. The sample is daily data between $9 / 7 / 1931$ and 10/8/1931 or 28 days when data were reported. We omit the day of sterling's devaluation, 9/21/1931, from the estimating sample. Each bond is identified with a currency of repayment and a country/colony. Robust, standard errors clustered at the country level are in brackets. ${ }^{* * *}$ p-value $<0.01 ;{ }^{* *}$ p-value $<0.05{ }^{*}$ p-value $<0.10$. 
Table 4 Determinants of the Absolute Change in GBP Exchange Rates, 1932

\begin{tabular}{|c|c|c|c|c|c|}
\hline & $(1)$ & $(2)$ & $(3)$ & $(4)$ & $(5)$ \\
\hline Bilateral Trade/GDP & $\begin{array}{c}-17.70^{* * *} \\
\lceil 2.90\rceil\end{array}$ & $\begin{array}{c}-13.72^{* * *} \\
\lceil 1.46\rceil\end{array}$ & $\begin{array}{c}-18.22^{* * *} \\
\lceil 2.20\rceil\end{array}$ & $\begin{array}{c}-12.77^{* * *} \\
\lceil 4.89\rceil\end{array}$ & $\begin{array}{c}-17.68^{* * *} \\
\lceil 2.74\rceil\end{array}$ \\
\hline Bilateral Debt/Exports & $\begin{array}{l}-0.19 \\
\lceil 0.11\rceil\end{array}$ & $\begin{array}{c}0.33^{* * *} \\
\lceil 0.07\rceil\end{array}$ & $\begin{array}{c}0.34^{* * *} \\
\lceil 0.06\rceil\end{array}$ & $\begin{array}{c}-0.24^{* *} \\
\lceil 0.12\rceil\end{array}$ & $\begin{array}{c}-0.35^{* * *} \\
\lceil 0.13\rceil\end{array}$ \\
\hline $\begin{array}{l}\text { Bilateral Trade/GDP x Bilateral } \\
\text { Debt/Exports }\end{array}$ & & $-16.64^{* * *}$ & $-15.24^{* * *}$ & & $2.46^{* * *}$ \\
\hline Change in $\ln$ (reserves) & & $\lceil 1.60\rceil$ & $\begin{array}{c}\lceil 1.43\rceil \\
-0.42^{* * *} \\
\lceil 0.09\rceil\end{array}$ & & $\lceil 0.63\rceil$ \\
\hline Trade/GDP & $\begin{array}{c}3.12^{* * *} \\
\lceil 0.77\rceil\end{array}$ & $\begin{array}{c}2.53^{* * *} \\
\lceil 0.52\rceil\end{array}$ & $\begin{array}{c}3.40^{* * *} \\
\lceil 0.49\rceil\end{array}$ & $\begin{array}{c}1.43 \\
\lceil 1.02\rceil\end{array}$ & $\begin{array}{c}2.03^{* * *} \\
\lceil 0.52\rceil\end{array}$ \\
\hline Foreign debt service/GDP & $\begin{array}{c}16.50^{* *} \\
\lceil 7.58\rceil\end{array}$ & $\begin{array}{c}26.18^{* * *} \\
\lceil 4.05\rceil\end{array}$ & $\begin{array}{c}6.86 \\
\lceil 5.14\rceil\end{array}$ & $\begin{array}{c}21.21^{* *} \\
\lceil 8.85\rceil\end{array}$ & $\begin{array}{c}16.09 * * \\
\lceil 8.06\rceil\end{array}$ \\
\hline
\end{tabular}

\section{Observations}

11
11 11 14 14

Notes: Dependent variable in the regression is the absolute change in the logarithm of the GBP exchange rate (local currency units per GBP) between 1932 and 1931. Estimation is by Poisson PPML. Robust standard errors are in brackets. ${ }^{* * *}$ p-value $<0.01 ; * *$ p-value $<0.05$; $^{*}$ p-value $<0.10$. 
Table 5 Absolute Changes in Bilateral Exchange Rates against the US and GB, 19251939, Panel Models

\begin{tabular}{|c|c|c|c|c|c|c|}
\hline & $(1)$ & $(2)$ & $(3)$ & $(4)$ & $(5)$ & $(6)$ \\
\hline Bilateral Trade/Y & $\begin{array}{c}-5.44^{* * *} \\
\lceil 1.54\rceil\end{array}$ & $\begin{array}{c}-6.22^{* * *} \\
\lceil 1.62\rceil\end{array}$ & $\begin{array}{c}-6.25^{* * *} \\
\lceil 1.53\rceil\end{array}$ & $\begin{array}{c}-5.71^{* * *} \\
\lceil 1.22\rceil\end{array}$ & $\begin{array}{l}-5.24^{* * *} \\
\lceil 1.16\rceil\end{array}$ & $\begin{array}{c}-5.58^{* * *} \\
\lceil 1.13\rceil\end{array}$ \\
\hline Bilateral Debt/Exports & $\begin{array}{c}-0.44 * * * \\
\lceil 0.10\rceil\end{array}$ & $\begin{array}{c}-0.45^{* * *} \\
\lceil 0.13\rceil\end{array}$ & $\begin{array}{c}-0.47^{* * *} \\
{[0.12\rceil}\end{array}$ & $\begin{array}{c}-0.72^{* * *} \\
{[0.10\rceil}\end{array}$ & $\begin{array}{l}-0.63^{* * *} \\
\lceil 0.09\rceil\end{array}$ & $\begin{array}{c}-0.76^{* * *} \\
{[0.11]}\end{array}$ \\
\hline$\{$ Bilateral Debt/Exports $\} \times$ Default & $\begin{array}{c}0.01 \\
\lceil 0.25\rceil\end{array}$ & $\begin{array}{l}-0.07 \\
\lceil 0.27\rceil\end{array}$ & $\begin{array}{l}-0.08 \\
\lceil 0.27\rceil\end{array}$ & $\begin{array}{c}0.55 * * * \\
{[0.16]}\end{array}$ & $\begin{array}{l}0.44^{* *} \\
\lceil 0.19\rceil\end{array}$ & $\begin{array}{c}0.64^{* * *} \\
{[0.21\rceil}\end{array}$ \\
\hline Default & $\begin{array}{l}0.51^{*} \\
\lceil 0.28\rceil\end{array}$ & $\begin{array}{l}0.50^{*} \\
\lceil 0.25\rceil\end{array}$ & $\begin{array}{c}0.50^{* *} \\
\lceil 0.25\rceil\end{array}$ & $\begin{array}{l}-0.45 \\
\lceil 0.41\rceil\end{array}$ & $\begin{array}{l}-0.69 * \\
\lceil 0.39\rceil\end{array}$ & $\begin{array}{l}-0.51 \\
\lceil 0.42\rceil\end{array}$ \\
\hline $\begin{array}{l}{[\text { Debt }(\mathrm{j}) / \text { Exports] x [Bilateral }} \\
\text { Trade/GDP] }\end{array}$ & $4.71^{* * *}$ & $5.37^{* * *}$ & $5.73^{* * *}$ & $8.16^{* * *}$ & $6.56^{* * *}$ & $8.40^{* * *}$ \\
\hline Trade/GDP t-1 & $\begin{array}{c}\lceil 0.86\rceil \\
-0.23 \\
\lceil 0.35\rceil\end{array}$ & $\begin{array}{c}\lceil 1.26\rceil \\
0.08 \\
\lceil 0.35\rceil\end{array}$ & $\begin{array}{c}\lceil 1.07\rceil \\
0.14 \\
\lceil 0.36\rceil\end{array}$ & $\begin{array}{l}\lceil 1.14\rceil \\
-0.55 \\
\lceil 0.75\rceil\end{array}$ & $\begin{array}{l}\lceil 0.89\rceil \\
0.41 \\
\lceil 0.60\rceil\end{array}$ & $\begin{array}{l}\lceil 1.46\rceil \\
-0.28 \\
\lceil 1.03\rceil\end{array}$ \\
\hline Foreign Debt Service/GDP & $\begin{array}{c}15.32 \\
\lceil 11.51]\end{array}$ & $\begin{array}{c}9.89 \\
\lceil 13.40]\end{array}$ & $\begin{array}{c}9.95 \\
\lceil 13.95\rceil\end{array}$ & $\begin{array}{l}-13.43 \\
\lceil 12.73\rceil\end{array}$ & $\begin{array}{l}-31.66^{*} \\
\lceil 17.40\rceil\end{array}$ & $\begin{array}{c}-24.51^{*} \\
\lceil 14.78\rceil\end{array}$ \\
\hline Chg. ln (reserves) & & $\begin{array}{c}-0.90^{* * *} \\
{[0.16\rceil}\end{array}$ & $\begin{array}{c}-0.99 * * * \\
\lceil 0.20\rceil\end{array}$ & $\begin{array}{c}-0.94^{* * *} \\
{[0.22\rceil}\end{array}$ & $\begin{array}{l}-0.64^{* * *} \\
\lceil 0.22\rceil\end{array}$ & $\begin{array}{c}-0.86 * * * \\
{[0.26\rceil}\end{array}$ \\
\hline Chg. $\ln (\mathrm{Ex} / \mathrm{Im})$ & & & $\begin{array}{l}-0.81 \\
\lceil 0.53\rceil\end{array}$ & $\begin{array}{l}-0.64 \\
\lceil 0.49\rceil\end{array}$ & $\begin{array}{l}-0.99^{*} \\
\lceil 0.56\rceil\end{array}$ & $\begin{array}{l}-0.24 \\
\lceil 0.34\rceil\end{array}$ \\
\hline $\begin{array}{l}\text { \% Change in GDP per capita since } \\
1928\end{array}$ & & & & & $\begin{array}{l}-3.49 * * * \\
{[1.09]}\end{array}$ & \\
\hline Observations & 296 & 296 & 296 & 296 & 294 & 255 \\
\hline Number of Countries & 13 & 13 & 13 & 13 & 13 & 11 \\
\hline Country Fixed Effects & $\mathrm{NO}$ & $\mathrm{NO}$ & NO & YES & YES & YES \\
\hline
\end{tabular}

Notes: Dependent variable in the regression is the absolute change in the logarithm of the GBP exchange rate or the USD exchange rate. Changes are annual changes for a sample ranging over the years 1925 to 1938. Estimation is by Poisson PPML. Robust standard errors, clustered at the country level are in brackets. ${ }^{* * *}$ p-value $<0.01 ; * *$ p-value $<$ $0.05 ;{ }^{*}$ p-value $<0.10$. 